\title{
Evaluation of the Impacts of Marine Salts and Asian Dust on the Forested Yakushima Island Ecosystem, a World Natural Heritage Site in Japan
}

\author{
Takanori Nakano • Yoriko Yokoo • \\ Masao Okumura $\cdot$ Seo-Ryong Jean • \\ Kenichi Satake
}

Received: 1 May 2012 / Accepted: 15 August 2012 /Published online: 12 September 2012

(C) The Author(s) 2012. This article is published with open access at Springerlink.com

\begin{abstract}
To elucidate the influence of airborne materials on the ecosystem of Japan's Yakushima Island, we determined the elemental compositions and $\mathrm{Sr}$ and $\mathrm{Nd}$ isotope ratios in streamwater, soils, vegetation, and rocks. Streamwater had high $\mathrm{Na}$ and $\mathrm{Cl}$ contents, low $\mathrm{Ca}$ and $\mathrm{HCO}_{3}$ contents, and $\mathrm{Na} / \mathrm{Cl}$ and $\mathrm{Mg} / \mathrm{Cl}$ ratios close to those of seawater, but it had low $\mathrm{pH}$ (5.4 to 7.1), a higher $\mathrm{Ca} / \mathrm{Cl}$ ratio than seawater, and distinct ${ }^{87} \mathrm{Sr} /{ }^{86} \mathrm{Sr}$ ratios that depended on the bedrock type.
\end{abstract}

T. Nakano $(\bowtie)$

Research Institute for Humanity and Nature,

457-4 Kamigamo Motoyama, Kita-ku,

Kyoto 603-8047, Japan

e-mail: nakanot@chikyu.ac.jp

Y. Yokoo

Department of Environmental Systems Science, Doshisha University,

1-3 Tataratuya,

Kyotanabe, Kyoto 610-0331, Japan

M. Okumura

Japan Oil, Gas and Metals National Corporation,

1310 Omiya, Saiwai-ku,

Kawasaki 212-8554, Japan

S.-R. Jean

Department of Geoscience, Chonbuk National University, 664-1,

567-756 Jeonju, Jeollabukdo, South Korea

K. Satake

Faculty of Geo-environmental Science, Rissho University, 1700 echi,

Kumagaya, Saitama 360-0194, Japan
The proportions of rain-derived cations in streamwater, estimated by assuming that $\mathrm{Cl}$ was derived from sea salt aerosols, averaged $81 \%$ for $\mathrm{Na}, 83 \%$ for $\mathrm{Mg}, 36 \%$ for $\mathrm{K}, 32 \%$ for $\mathrm{Ca}$, and $33 \%$ for $\mathrm{Sr}$. The $\mathrm{Sr}$ value was comparable to the $28 \%$ estimated by comparing $\mathrm{Sr}$ isotope ratios between rain and granite bedrock. The soils are depleted in $\mathrm{Ca}, \mathrm{Na}, \mathrm{P}$, and $\mathrm{Sr}$ compared with the parent materials. At Yotsuse in the northwestern side, plants and the soil pool have ${ }^{87} \mathrm{Sr} /{ }^{86} \mathrm{Sr}$ ratios similar to that of rainwater with a high sea salt component. In contrast, the $\mathrm{Sr}$ and $\mathrm{Nd}$ isotope ratios of soil minerals in the $\mathrm{A}$ and $\mathrm{B}$ horizons approach those of silicate minerals in northern China's loess soils. The soil $\mathrm{Ca}$ and $\mathrm{P}$ depletion results largely from chemical weathering of plagioclase and of small amounts of apatite and calcite in granitic rocks. This suggests that Yakushima's ecosystem is affected by large amounts of acidic precipitation with a high sea salt component, which leaches $\mathrm{Ca}$ and its proxy $(\mathrm{Sr})$ from bedrock into streams, and by Asian dust-derived apatite, which is an important source of $\mathrm{P}$ in base cation-depleted soils.

Keywords Yakushima - Asian dust - Stream water . Chemical weathering $\cdot \mathrm{Sr}$ isotope $\cdot \mathrm{Nd}$ isotope .

Ca depletion

\section{Introduction}

The atmosphere of the Japanese archipelago is rich in marine aerosols from the surrounding ocean and has 
been adversely affected by acidic pollutants and dust minerals transported from the Asian continent (Hatakeyama et al. 2004; Shimizu et al. 2004; Inoue et al. 2005; Nakano et al. 2006; Seto et al. 2007; Hartmann et al. 2008). Monitoring studies over more than 10 years have shown the acid rain impact on soil and aquatic ecosystems in the mountainous area of Japan (e.g., Kurita and Ueda 2006; Nakahara et al. 2010). However, few researchers have evaluated the impacts of atmospheric deposition of continentalderived materials on Japan's terrestrial and aquatic ecosystems. The effects of rain and aerosols on biogeochemical cycles are so complex that an integrated approach that considers entire ecological systems as single interacting units is required to understand these effects. Nutrients and other ions in the soil-vegetation system and in terrestrial water are ultimately derived not only from the atmosphere but also from weathering of the soil and the underlying bedrock. Accordingly, identification and quantification of atmosphere- or bedrock-derived materials in plants, soils, and streamwater are important for assessing the biogeochemical cycles in terrestrial ecosystems.

Rainwater in Japan has ${ }^{87} \mathrm{Sr} /{ }^{86} \mathrm{Sr}$ ratios that clearly differ from those of the substrate rocks at depositional sites, and it contains high quantities of $\mathrm{Sr}$ and $\mathrm{Ca}$ that are derived from acid-soluble minerals (mainly calcium carbonate) that originated in the desert and loess areas of northern China (Nakano and Tanaka 1997; Nakano et al. 2006). Sr is a good proxy for Ca (Miller et al. 1993; Áberg 1995; Clow et al. 1997), which is essential for plant growth (as are K, P, and Si), and the ${ }^{87} \mathrm{Sr} /{ }^{86} \mathrm{Sr}$ ratios of water and vegetation are affected by the ratios present in a basin's bedrock (Graustein 1988; Faure and Mensing 2005). The ${ }^{87} \mathrm{Sr} /{ }^{86} \mathrm{Sr}$ ratio and concentrations of dissolved ions in rainwater show temporal variation (Nakano and Tanaka 1997; Nakano et al. 2006), whereas those of a stream's base flow are temporally invariant and can therefore be considered to represent year-round water characteristics (Rose and Fullagar 2005). Accordingly, $\mathrm{Sr}$ isotopes have been utilized as powerful tracers for determining the sources and flows of $\mathrm{Ca}$ within soil-vegetation systems (e.g., Miller et al. 1993; Áberg 1995; Blum et al. 2002) and aquatic systems (e.g., Clow et al. 1997; Shand et al. 2009). Nd isotopes also have considerable potential as atmospheric and environmental tracers, since the soils in northern China are reported to have ${ }^{143} \mathrm{Nd} /{ }^{144} \mathrm{Nd}$ ratios ( $\varepsilon_{\mathrm{Nd}}$ values) that are distinct from those of many rocks in Japan (Bory et al. 2003; Nakano et al. 2004). Several $\mathrm{Sr}$ and Nd isotope studies have shown that Asian dust minerals are deposited in the soils of southwestern Japan (Mizota et al. 1992) and Hawaii (Chadwick et al. 1999; Kurtz et al. 2001), but few studies have used both isotopes as biogeochemical tracers in terrestrial systems (Pett-Ridge et al. 2009).

Yakushima Island, in southwestern Japan (Fig. 1), became a world natural heritage site in 1993 in recognition of its unique and irreplaceable forested ecosystem. This island faces the Asian continent across the East China Sea, and rainfall and some tree (Pinus amamiana) on the island are intensely affected by aerosols from the surrounding sea and by acidic materials, including gases (SOx and NOx) and aerosols, transported from China (Satake et al. 1998; Nakano et al. 2000; Nagafuchi et al. 2001; Kume et al. 2010). The annual average $\mathrm{pH}$ of rain on Yakushima is 4.7 , a value equivalent to that on the main islands of Japan (Tamaki et al. 1991; Japan Environmental Sanitation Center 2002). However, the mean annual precipitation on Yakushima ranges from 2,500 to 4,700 $\mathrm{mm}$ at lower altitudes along the coast, and it exceeds $8,600 \mathrm{~mm}$ in mountainous areas (Eguchi 1984). These amounts are three to five times the precipitation on the main Japanese islands, indicating that Yakushima is receiving proportionally higher total inputs of acidic materials in precipitation. Further, the geology of Yakushima is widely composed of granite, which is known to have small acid neutralization capacity. Nevertheless, the impact of rain and dust minerals from the Asian continent on the island's plants, soils, and streamwater is unclear. This study was undertaken to elucidate the geochemical and $\mathrm{Sr}$ and $\mathrm{Nd}$ isotopic characteristics of Yakushima's aquatic, soil, and vegetation systems and their responses to these atmospheric inputs.

\section{Study Site and Methodology}

\subsection{Geography and Geology}

Yakushima Island is located $70 \mathrm{~km}$ south of Kyushu $\left(30^{\circ} \mathrm{N}, 130^{\circ} \mathrm{E}\right)$, Japan's third largest island. This small island, $132 \mathrm{~km}$ in circumference and $503 \mathrm{~km}^{2}$ in area, consists of steep mountains covered by dense natural forests with many cliffs and with many waterfalls owing to the large amounts of precipitation. Mt. 
Fig. 1 Upper map location of Yakushima Island and the study sites: I, Yakushima Island; II, Tanegashima; III, northern Kagoshima; $I V$,

Naegi; and $V$, Tsukuba. Bottom map sampling sites locations and geological background of Yakushima. Red circles, black triangles, and empty squares represent streamwater sampling points in areas with bedrock dominated by granite, bedrock dominated by sedimentary rocks of the Kumage group, and mixtures of the two types of rocks, respectively. The large empty square indicates the Yotsuse sample site discussed in the text. Three large filled squares indicate the locations of the rainwater monitoring and sampling by Tamaki et al. (1991), Satake et al. (1998), and Nakano et al. (2000).

Sampling locations in areas with granitic bedrock are 23, $39,45,57,66$, and 83, and those in areas with Kumage sedimentary rocks are 14 , 60 , and 82 . The sites where both streamwater and bedrock were collected are shown in boldface. Diamonds indicate the sampling sites of soil in Nakano et al. (2001c)

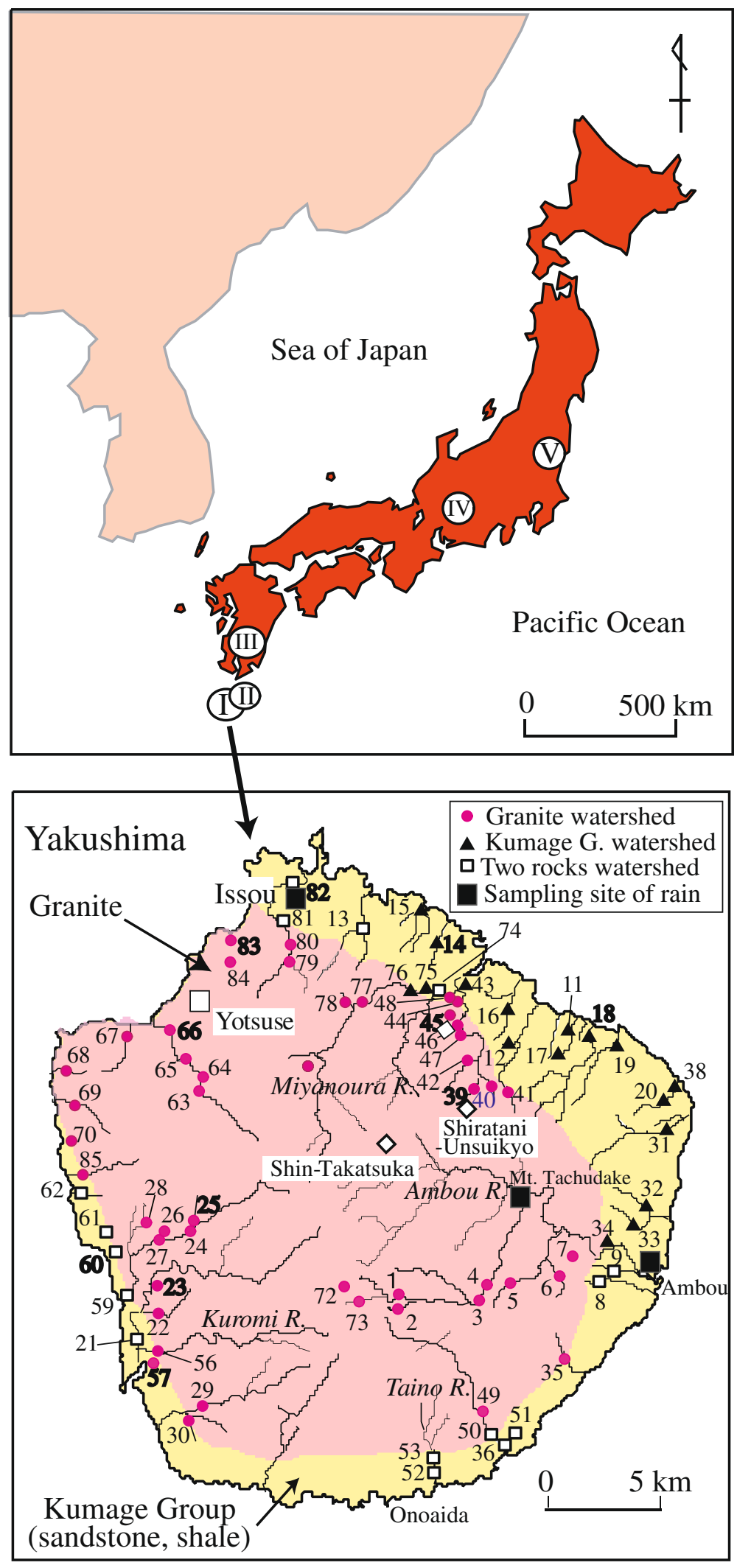


Miyanoura, the highest point on the island, at 1,935 $\mathrm{m}$ above sea level (a.s.1.), is also the highest peak in the Kyushu region. The annual mean temperature is around $20{ }^{\circ} \mathrm{C}$ at the coast; this corresponds to the margin between the subtropical and warm temperate zones (Tagawa 1994); however, the temperature decreases with increasing elevation, and areas above $1000 \mathrm{~m}$ a.s.l. receive snow in winter. Accordingly, there are distinct altitudinal zones of vegetation. About 14,000 residents live in small areas of Yakushima, mostly along the coast at elevations less than $100 \mathrm{~m}$ a.s.l.

The island is composed mainly of Miocene granites of the ilmenite series that contain orthoclase megacrysts with maximum lengths of $14 \mathrm{~cm}$, as well as plagioclase, quartz, and biotite, with small amounts of chlorite, apatite, zircon, tourmaline, muscovite, and ilmenite (Sato and Nagashima 1979). Anma et al. (1998) classified Yakushima's granite into four types on the basis of its occurrence, texture, and petrochemistry: the Yakushima main granite, the core granodiorite, the core cordierite granodiorite, and the core cordierite granite. The Yakushima main granite occupies $90 \%$ of the total area of the Yakushima pluton, whereas the other granites are locally distributed. The Yakushima granite body is an intrusion within the Kumage Group, which originated in the Paleogene age and is composed mainly of sandstone and shale distributed around the periphery of the island. These sedimentary materials are sometimes overlain unconformably by terrace deposits, talus deposits, and Quaternary alluvium, mainly along the eastern and southern coasts. A pyroclastic flow deposit called Akahoya covers these rocks in some areas.

\subsection{Samples}

There are three sites (Issou, Tachudake, and Ambou in Fig. 1) for monitoring the precipitation chemistry in Yakushima. Detailed compositional data are available for the Issou site, where rainwater was collected with a bulk sampler at intervals of 1 or 2 weeks from 1994 to 1996. This site is about $250 \mathrm{~m}$ above sea level and $5 \mathrm{~m}$ from the ground, on top of a building, and trees, as viewed from the sampler, cover less than $30^{\circ}$ of the sky (i.e., there is little or no interference from trees).

From 1996 to 1997 we sampled streamwater at 79 locations chosen on the basis of their basin geology during the baseflow period from summer to autumn
(Fig. 1). These samples were divided into three groups: those in granite-dominated watersheds, those in watersheds dominated by the Kumage sedimentary rock, and those in watersheds that include both types of rock. For comparison of streamwater quality in relation with the watershed geology, we sampled streamwater from several areas with a range of geological conditions and with negligible upstream human activity on Tanegashima Island, which is close to Yakushima and composed primarily of sedimentary rock; in the northern part of Kagoshima Island, which is composed primarily of granitic rock, sedimentary rock, and volcanic rock (mostly andesitic); in the Naegi area of Chubu district, which is composed mostly of granite; and in the Tsukuba area of Ibaraki prefecture, which is composed mostly of granite and gabbro (Fig. 1). At each site, the water samples were filtered through disposable cellulose acetate filters with a pore size of $0.2 \mu \mathrm{m} ; \mathrm{pH}$ and alkalinity were measured immediately after sampling.

We also collected eight granite samples at six locations and four samples of the Kumage sedimentary rocks at four locations (Fig. 1). Soil is well developed on the hills and gentle slopes. At the Yotsuse site in the northwestern part of Yakushima, facing the Asian continent (Fig. 1), we collected samples of three plant species and soil samples at seven depths. This site is located at the top of a small hill (200 m a.s.1.), where the granitic bedrock is deeply weathered to produce horizons in the soil profile; the thicknesses of the A horizon and the $\mathrm{B}$ horizon were 30 and $170 \mathrm{~cm}$, respectively, whereas the $\mathrm{C}$ horizon reached a depth of more than $500 \mathrm{~cm}$.

\subsection{Analysis}

We dried about $40 \mathrm{~g}$ of soil from each horizon overnight at $105{ }^{\circ} \mathrm{C}$ in an oven. The dried samples were then reacted with $10 \% v / v$ hydrogen peroxide $\left(\mathrm{H}_{2} \mathrm{O}_{2}\right)$ solution in a tall beaker at $70{ }^{\circ} \mathrm{C}$ to separate the organic fraction. The solution was then centrifuged (Kokusan Enshinki, H-103N Series) at 2,400 rpm for $30 \mathrm{~min}$. The supernatant was used for the $\mathrm{Sr}$ isotope analysis. The residual fraction was washed with ultrapure water; after centrifugation for $30 \mathrm{~min}$, this supernatant was then discarded. We collected residual soils after repeating this rinse procedure three times. Three soil fractions $(<2,2$ to 20 , and $>20 \mu \mathrm{m})$ were separated from about $10 \mathrm{~g}$ of the residual soil by means of 
Stokes' law gravity sedimentation in deionized water. They were then concentrated by centrifugation. Bulk soils and these fractions were digested with a solution of $\mathrm{HF}, \mathrm{HClO}_{4}$, and $\mathrm{HNO}_{3}$. We also extracted soil samples of about $0.5 \mathrm{~g}$ with $1 \mathrm{~N}$ acetic acid (HOAc) solution to remove the exchangeable fraction. The remaining solution was used for the $\mathrm{Sr}$ isotope analysis. Rock samples were pulverized in a tungsten carbide vessel with a HERZOG HSM-F36 disk mill (HERZOG Automation Corp., Osnabrück, Germany) to obtain powdered samples for chemical and $\mathrm{Sr}$ isotope analysis. All reagents used in this leaching and dissolution procedure were of analytical grade or better.

Chemical analyses were performed at the Chemical Analysis Center and the Institute of Geoscience, University of Tsukuba. The concentrations of cations and anions in streamwater were determined by means of inductively coupled optical emission spectrometry (Jarrell Ash ICAP-757V, Kyoto, Japan) and a Yokokawa Analytical Systems (Yokogawa, Japan) IC7000 ion chromatograph, respectively. The chemical compositions of the rocks and soils were determined by means of X-ray fluorescence with a Phillips PW1404 analyzer. We determined $\mathrm{Sr}$ and Nd isotope ratios by using a Finnigan MAT 262RPQ mass spectrometer at the University of Tsukuba and a Thermo Fisher TRITON mass spectrometer at the Research Institute for Humanity and Nature. The mean ${ }^{87} \mathrm{Sr} /{ }^{86} \mathrm{Sr}$ ratio of nine standard NBS987 samples during this study was $0.710246\left(2 \sigma_{\text {mean }}, \pm 0.000022 ; n=9\right)$ using the MAT262 RPQ and $0.710278\left(2 \sigma_{\text {mean }}\right.$, $\pm 0.000012 ; n=5)$ using the TRITON, and all measurements were normalized with respect to the recommended ${ }^{87} \mathrm{Sr} /{ }^{86} \mathrm{Sr}$ ratio of 0.710250 . The ${ }^{143} \mathrm{Nd} /{ }^{144} \mathrm{Nd}$ ratio of the La Jolla standard was $0.511846 \pm 0.000011$ $\left(2 \sigma_{\text {mean }}, n=12\right)$.

\section{Results and Discussion}

\subsection{Streamwater System}

\subsubsection{Geochemical Characteristics of Yakushima Streamwater}

Streamwater was classified into three types based on the geology of the upstream watershed of the sampling point. The chemical compositions of dissolved ions in the streamwater of Yakushima (Table 1) showed a large geographical variation, but did not differ significantly between the samples from watersheds with granitic bedrock and those with Kumage Group bedrock. The mean water quality values for streamwater in Yakushima for the two type's watershed geology and those from the other study areas are summarized in Table 2. Streamwater from all areas except Yakushima was neutral to slightly alkaline, but there was a tendency for the streamwater in granitic watersheds to be slightly more acidic than those in watersheds with sedimentary or volcanic rock (Fig. 2); the average $\mathrm{pH}\left( \pm \sigma_{\text {mean }}\right)$ values for streamwater in the granitic watershed (III, IV, and V in Table 2) and in watersheds with sedimentary or volcanic rock (II, III, and V in Table 2) were $6.87 \pm$ 0.28 and $7.26 \pm 0.27$, respectively.

This difference is consistent with the composition of granite, which is composed mainly of minerals that are resistant to chemical weathering (i.e., quartz and potassium feldspar) and that thus have a lower capacity to buffer acids in the rain. One remarkable feature is that the Yakushima streamwater was more acidic than that in the other basins, with $\mathrm{pH}$ ranging from 5.4 to 7.1 (an average of 6.5) versus a range of 6.7 to 8.0 at the other sites. Furthermore, the streamwater at the other sites was generally a $\mathrm{CaHCO}_{3}$ or $\mathrm{NaHCO}_{3}$ type, whereas the Yakushima streamwater was generally a $\mathrm{NaCl}$ type. The average $\mathrm{Na}$ and $\mathrm{Cl}$ concentrations in the Yakushima streamwater were about 7.6 and 4.7 times the average $\mathrm{Ca}$ and $\mathrm{HCO}_{3}$ concentrations, respectively.

Monthly analysis of the rainwater composition at the Issou site (Satake et al. 1998; Nakano et al. 2000) revealed that the concentrations of the major dissolved ions were high in winter and low in summer, but that the proportions of $\mathrm{Na}, \mathrm{Mg}$, and $\mathrm{Cl}$ (Fig. 2 in Nakano et al. 2000) were roughly constant throughout the year and were almost identical to those in seawater, indicating that these three ions are largely of sea salt origin. The non-sea salt (NSS) Ca and K fractions in the Yakushima rainwater were $0.6 \pm 0.2$ and $0.3 \pm 0.2$, respectively (Fig. 4 in Nakano et al. 2000). Nakano et al. (2000) suggested from their Sr isotope study that the NSS Ca is derived mainly from plant cover on Yakushima that dominantly contains $\mathrm{Sr}$ with a marine isotopic signature. Table 2 provides the mean $\mathrm{pH}$, electrical conductivity, and concentrations of the main ions in precipitation.

Chloride is assumed to be a conservative tracer for the input of sea salt aerosols (Berner and Berner 1987), and the ratio of a given cation to the $\mathrm{Cl}$ concentration in 


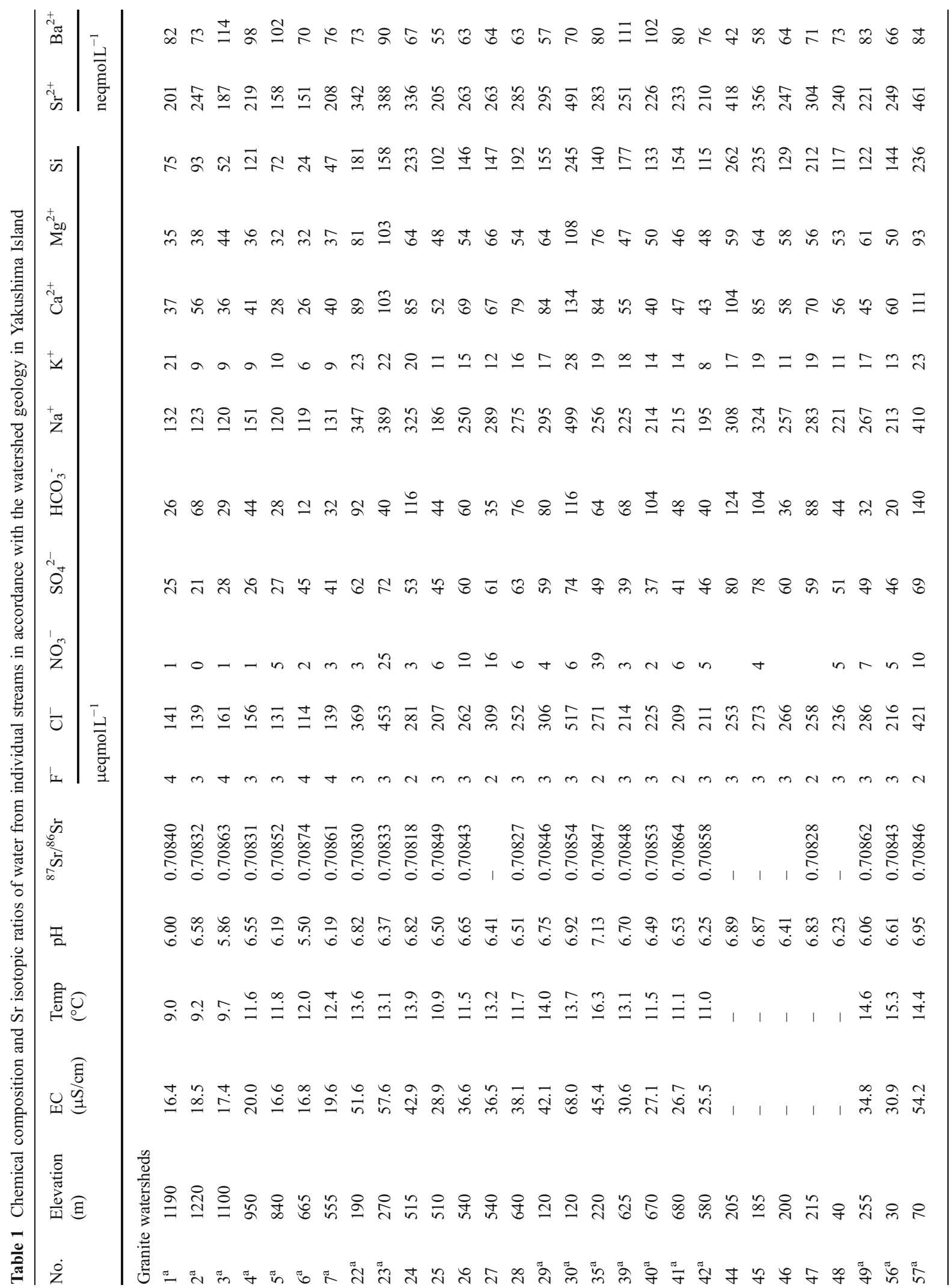




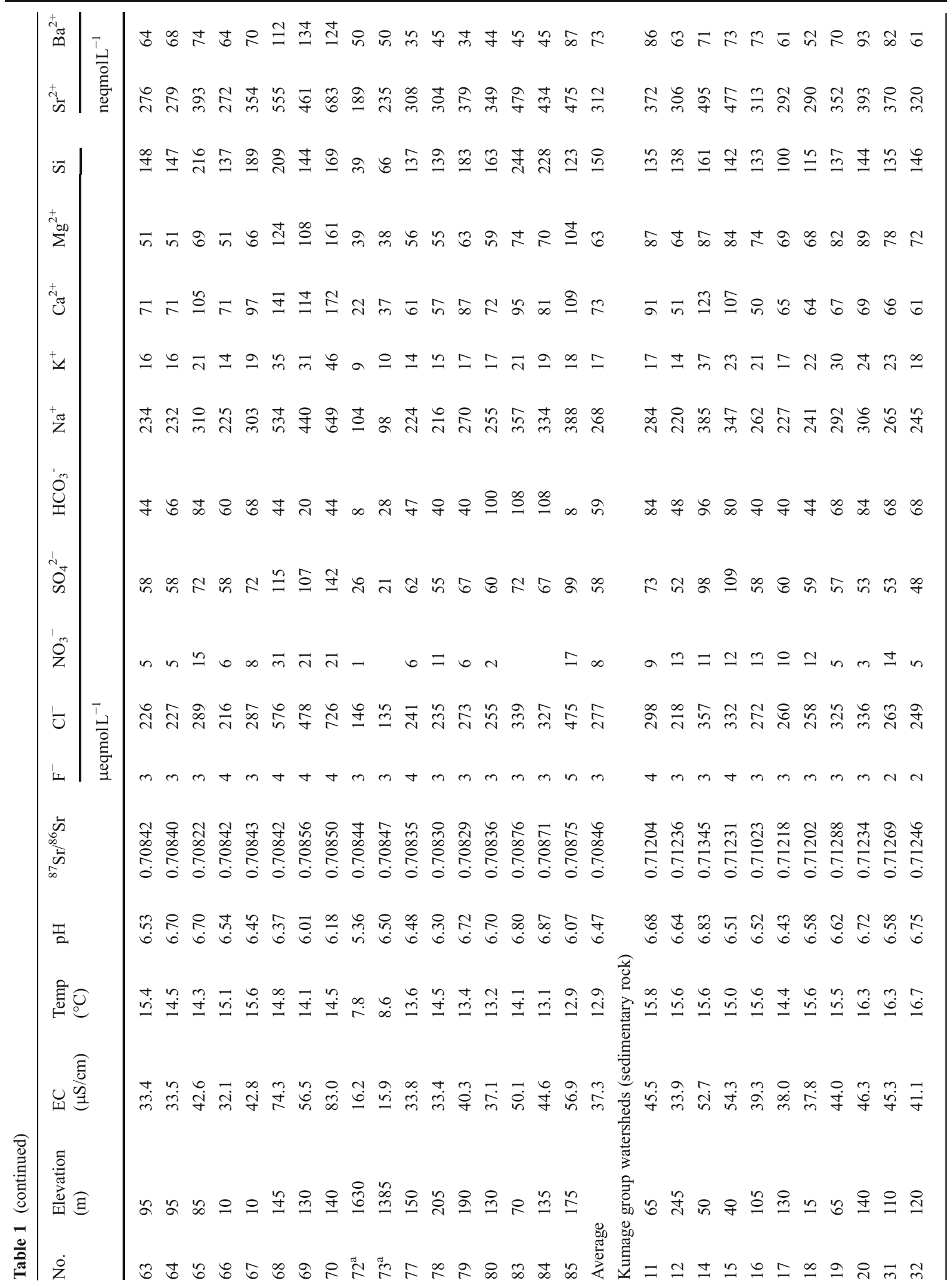




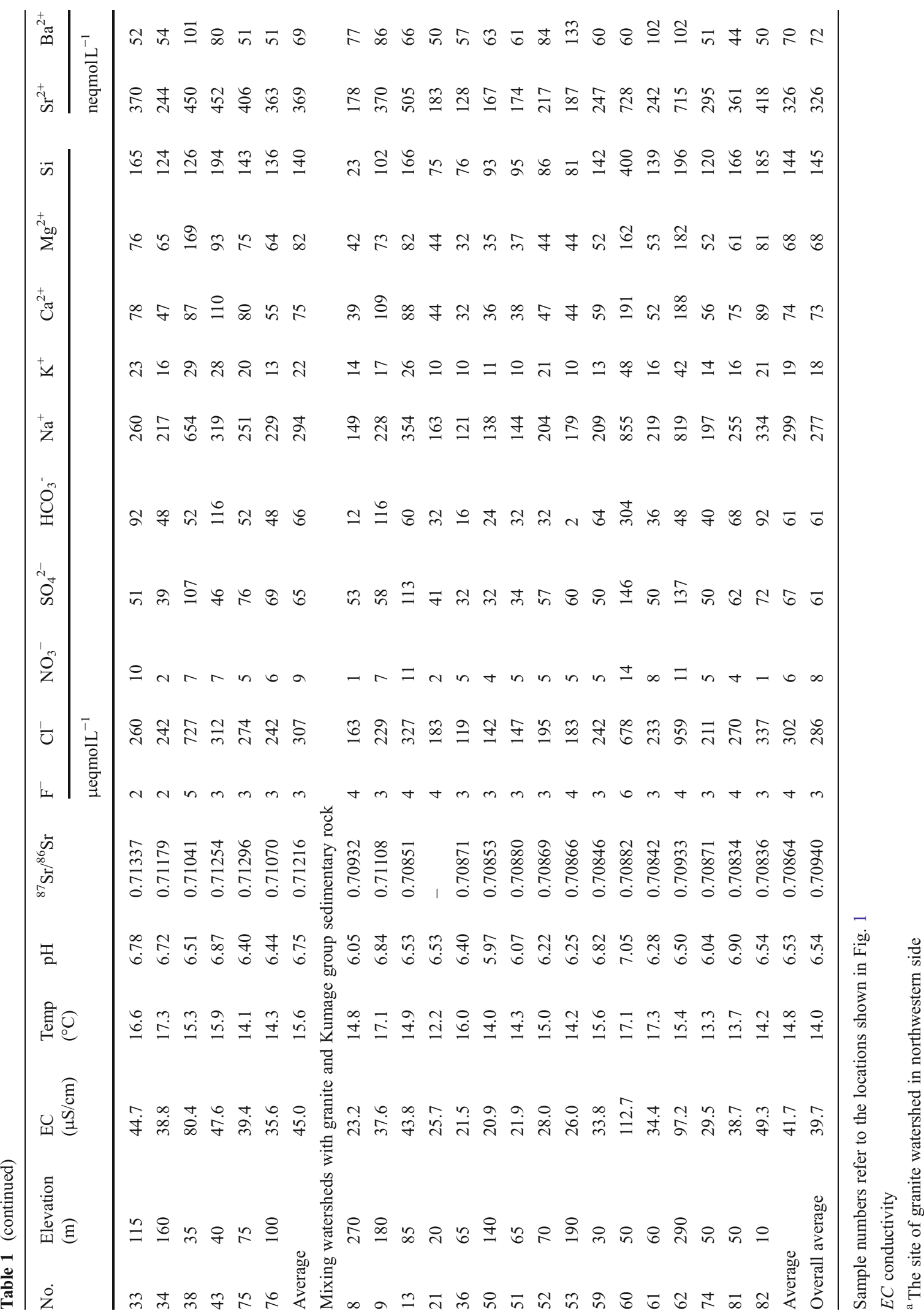




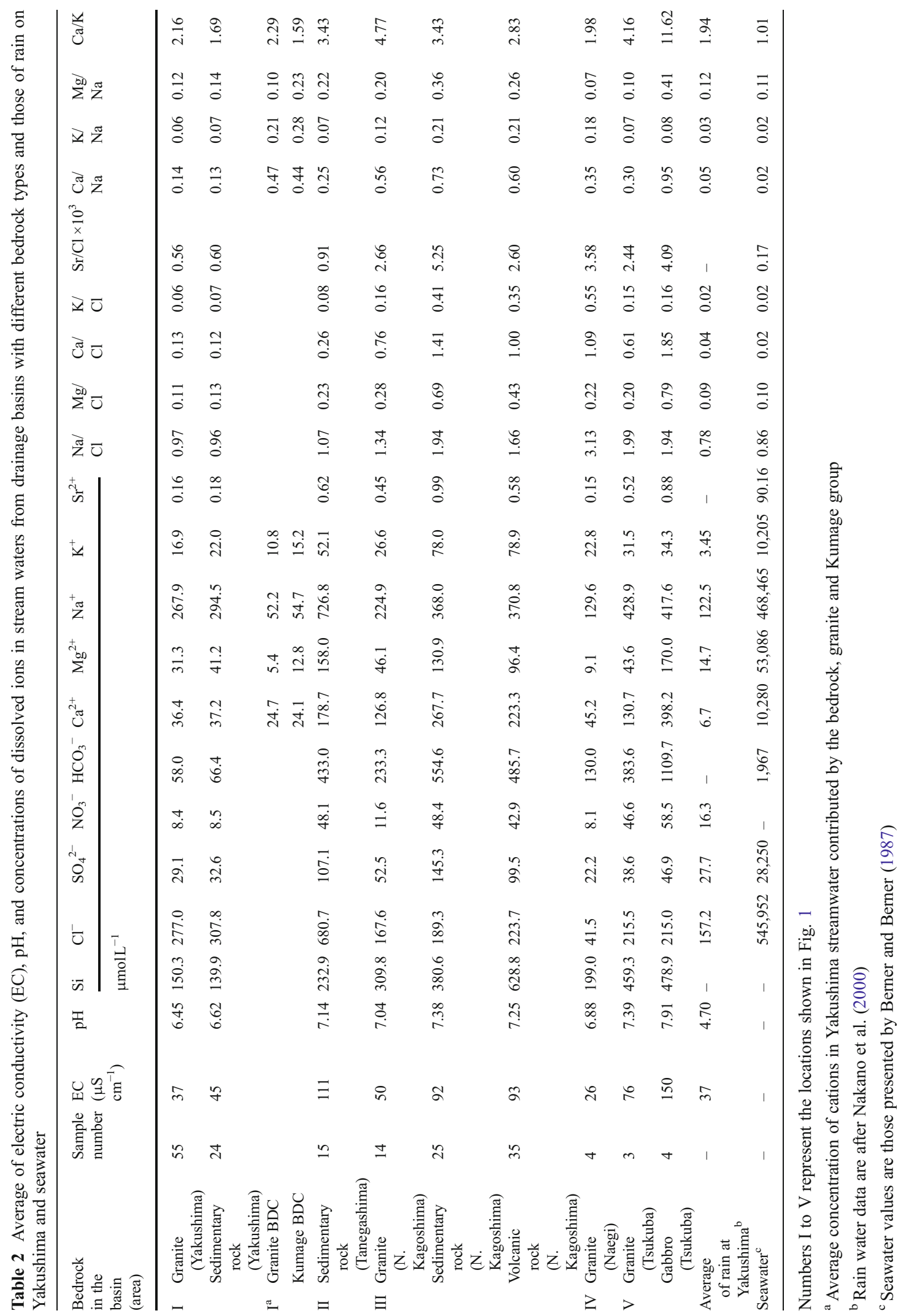



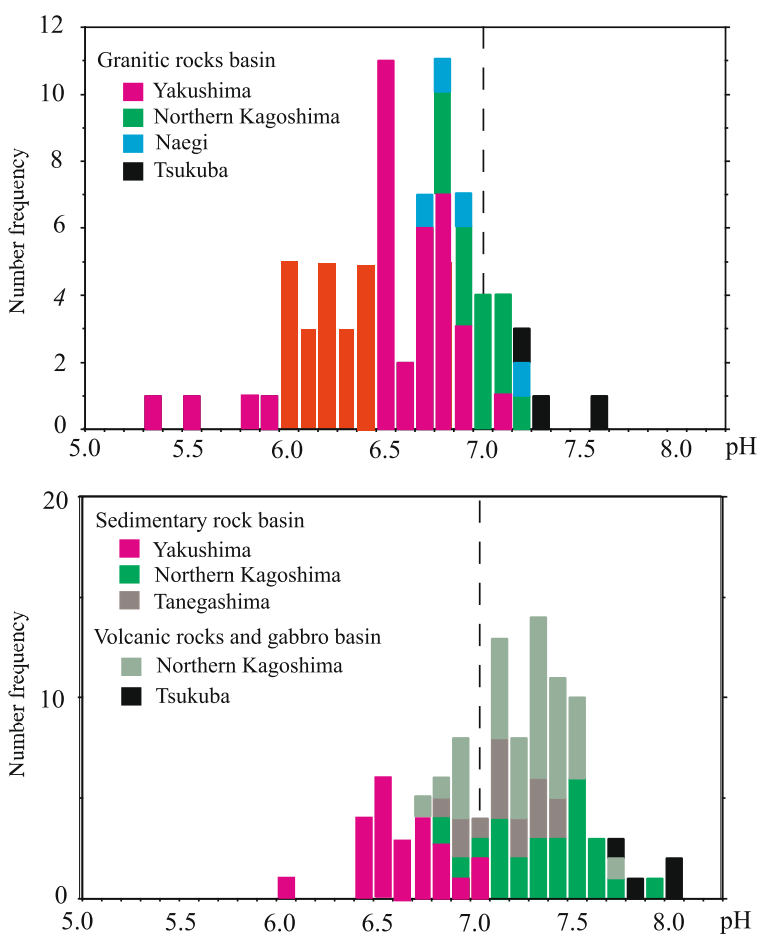

Fig. 2 Frequency distribution of streamwater $\mathrm{pH}$ in (upper graph) watersheds with granitic bedrock and (lower graph) watersheds with bedrock from the Kumage series of clastic sedimentary rocks, with volcanic rocks (mostly andesitic), and with gabbro. Vertical dashed lines represent neutral $\mathrm{pH}$ (7.0)

streamwater therefore increases as a result of addition of the cation to soil water through chemical weathering. The concentrations of the major cations $(\mathrm{Na}, \mathrm{K}, \mathrm{Ca}$, and $\mathrm{Mg}$ ) in Yakushima streamwater were positively correlated with the $\mathrm{Cl}$ concentration (Fig. 3). In addition, the $\mathrm{Na} / \mathrm{Cl}$ and $\mathrm{Mg} / \mathrm{Cl}$ ratios of the Yakushima streamwater were close to those of seawater (Table 2). Although the $\mathrm{Ca} / \mathrm{Cl}$ and $\mathrm{K} / \mathrm{Cl}$ ratios of the Yakushima streamwater were considerably higher than those of seawater (Table 2), the values were still closer to the seawater ratios than to those of streamwater from other areas of Japan. These results strongly suggest that the acidic precipitation on Yakushima contains a substantial sea salt component, which in turn controls the chemical composition of dissolved elements in the Yakushima streamwater.

The sea salt component of the rain generally decreases with increasing distance from the coast (Berner and Berner 1987). Tamaki et al. (1991) reported the average elemental composition of wet precipitation over 2 years at two Yakushima sites with different altitudes, Ambou at $40 \mathrm{~m}$ a.s.l. and Tachudake at
$475 \mathrm{~m}$ a.s.1. (Fig. 1). They found that rainfall on Yakushima had a lower annual average $\mathrm{Cl}$ concentration at $475 \mathrm{~m}$ than at $40 \mathrm{~m}$, but had the same annual average $\mathrm{pH}$ value (4.7). The concentration of $\mathrm{Cl}$ in the streamwater of Yakushima, where the watershed is small, tended to decrease with elevation (Fig. 4). At several low-elevation sites, the $\mathrm{Cl}$ content of the streamwater was very high $\left(>0.5 \mathrm{molL}^{-1}\right)$. Because of the high humidity that results from the heavy rainfall in the study area, this high $\mathrm{Cl}$ content in streamwater cannot be explained only by the concentration process that results from the evaporation of rainwater; instead, it suggests the dry deposition of sea spray in areas near the shore.

The positive correlations of cations in Yakushima streamwater with the $\mathrm{Cl}$ concentration indicate that the cation concentrations tend to decrease with elevation. The altitudinal decreases of $\mathrm{Cl}$ and cation concentrations in streamwater are likely to be caused by the increased contribution of rainfall at higher elevations, which increases the amount of water relative to the amount of sea salt. The correlation coefficient between $\mathrm{pH}$ and elevation for the Yakushima streamwater is -0.42 $(P<0.05)$, suggesting that, although the correlation is weak, streamwater at high elevations tends to be more acidic (Fig. 4). A similar pattern of decreasing streamwater $\mathrm{pH}$ with elevation has been observed in base-poor watersheds at the Hubbard Brook Experimental Forest (New Hampshire, USA) that have been affected by inputs of acidic deposition (Palmer et al. 2005). Accordingly, the altitudinal decrease of Yakushima streamwater $\mathrm{pH}$ value may be partly ascribed to the effects of the larger amount of acidic rain because the mountainous area receives a high input of $\mathrm{H}^{+}$ions from the atmosphere, and these cannot be fully neutralized by weathering of the granitic bedrock.

NSS sulfate (NSS $\mathrm{SO}_{4}$ ) is an important component responsible for the formation of acid rain. Nakano et al. (2001a) and Ebise and Nagafuchi (2002) reported that streamwater in the northwestern side of Yakushima island contained higher concentration of $\mathrm{NSS} \mathrm{SO}_{4}$ than that in the southeastern side (Fig. 5), and attributed this areal variation of streamwater to acidic deposition transported from the northwestern Asian continent. However, the concentration of non-sea salt cations such as NSS Ca in streamwaters of the granite watershed did not show a meaningful difference between the northwestern and southeastern sides compared to their altitudinal decreases. This result suggests that the chemical weathering of granite is affected by the amount of precipitation 


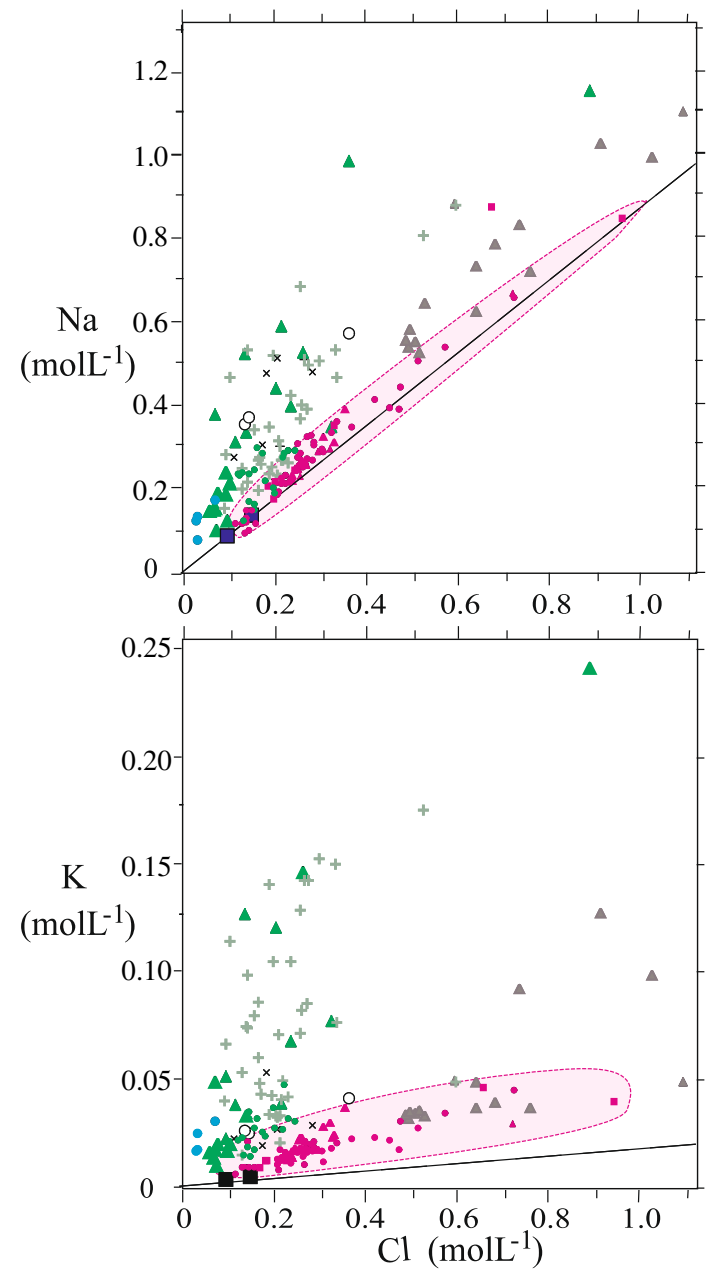

Fig. 3 Concentrations of the four major cations $(\mathrm{Na}, \mathrm{Mg}, \mathrm{K}$, $\mathrm{Ca}$ ) as functions of the $\mathrm{Cl}$ concentration in streamwater on Yakushima and in other areas with different bedrock geologies. Solid lines indicate values based on the ratios in seawater

and other acids such as carbonic and/or organic acids generating in soil-vegetation system rather than the atmosphere-derived $\mathrm{NSS} \mathrm{SO}_{4}$.

\subsubsection{Rainwater Contribution to Cations in Streamwater}

When there is no direct contribution from human activity, the ions dissolved in the streamwater should ultimately originate from the atmosphere and from the watershed's bedrock. In other words, dissolved ions in

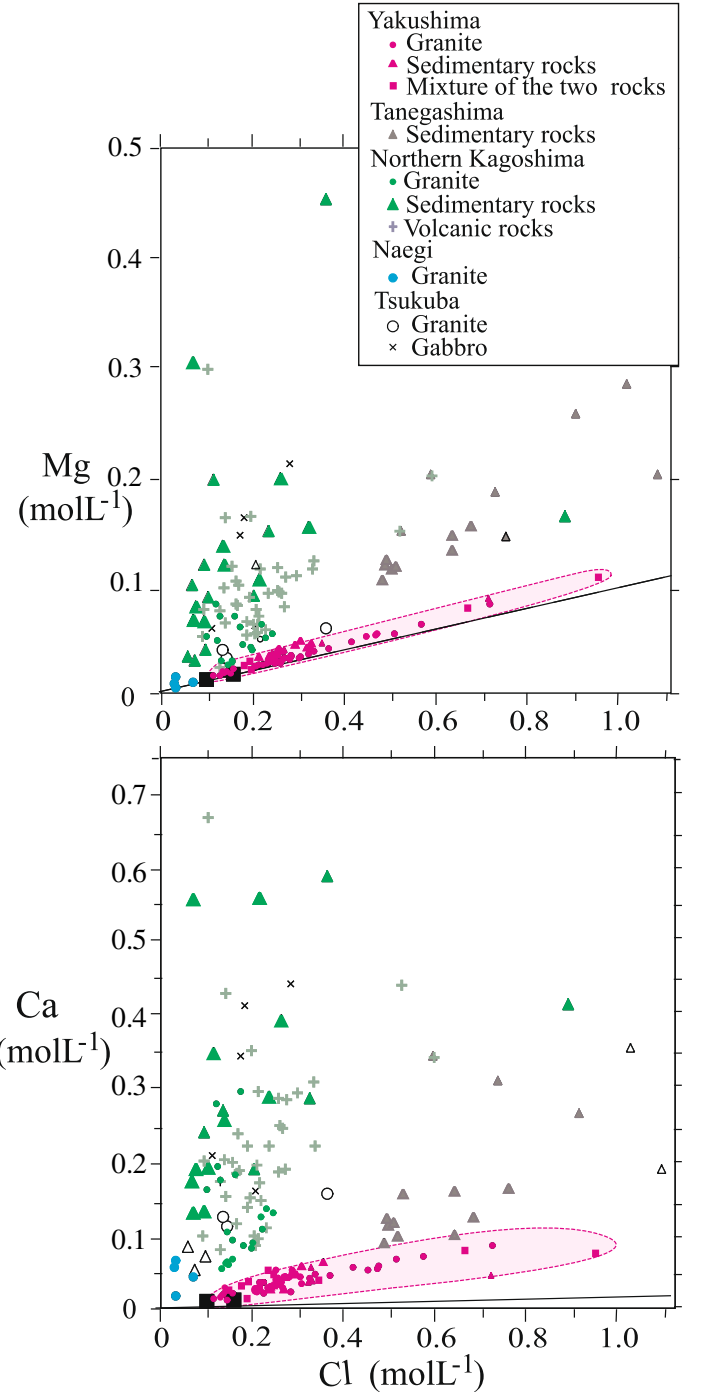

(Berner and Berner 1987). The two filled squares represent the mean compositions in rainwater at two sites [elevations of $475 \mathrm{~m}$ (high $\mathrm{Cl}$ ) and $40 \mathrm{~m}$ (low $\mathrm{Cl}$ )] on Yakushima in a study by Tamaki et al. (1991)

streamwater as well as in the soil water can be separated into an atmosphere-derived component and a bedrock-derived component (BDC), which can be subclassified into granite BDC for the BDC from the granites and Kumage BDC for the BDC from the Kumage sedimentary rocks. It is generally assumed that $\mathrm{Cl}$ in streamwater is derived mainly from precipitation when there is no volcanic gas or evaporites (both of which are enriched in $\mathrm{Cl}$ ) in the watershed (Berner and Berner 1987; Nakano et al. 2001b; Négrel et al. 2005). On the other hand, bedrock is generally 

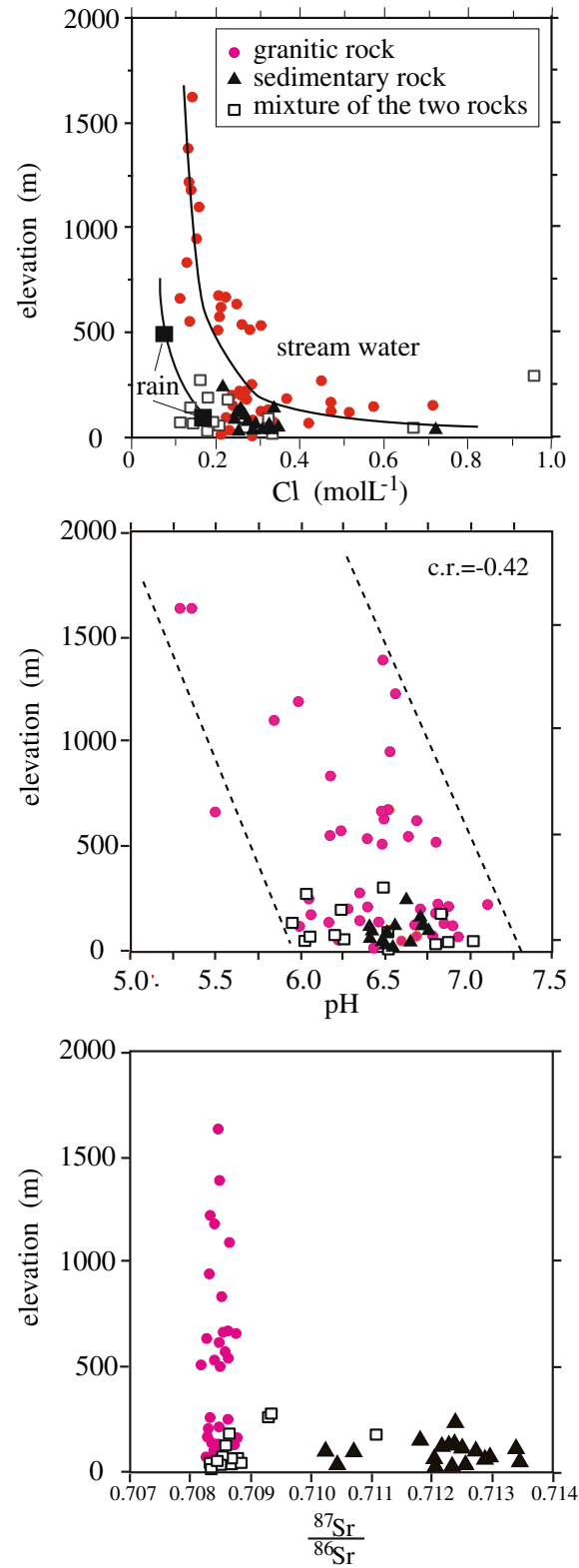

Fig. 4 Concentration of $\mathrm{Cl}$ (top), $\mathrm{pH}$ (middle), and ${ }^{87} \mathrm{Sr} /{ }^{86} \mathrm{Sr}$ ratios (bottom) in Yakushima streamwater as a function of elevation. Most streamwater samples from granite watersheds are from small drainage areas, and this can minimize the effects of the elevation at which the rainwater falls. The concentrations of $\mathrm{Cl}$ in rainwater at two sites on Yakushima (large filled squares) were taken from Tamaki et al. (1991)

considered to be the major source of cations in streamwater through chemical weathering. The concentrations of dissolved ions in water increase as a result of evaporation, but their ratios are generally assumed not to change substantially. Accordingly, the relatively elevation (m)
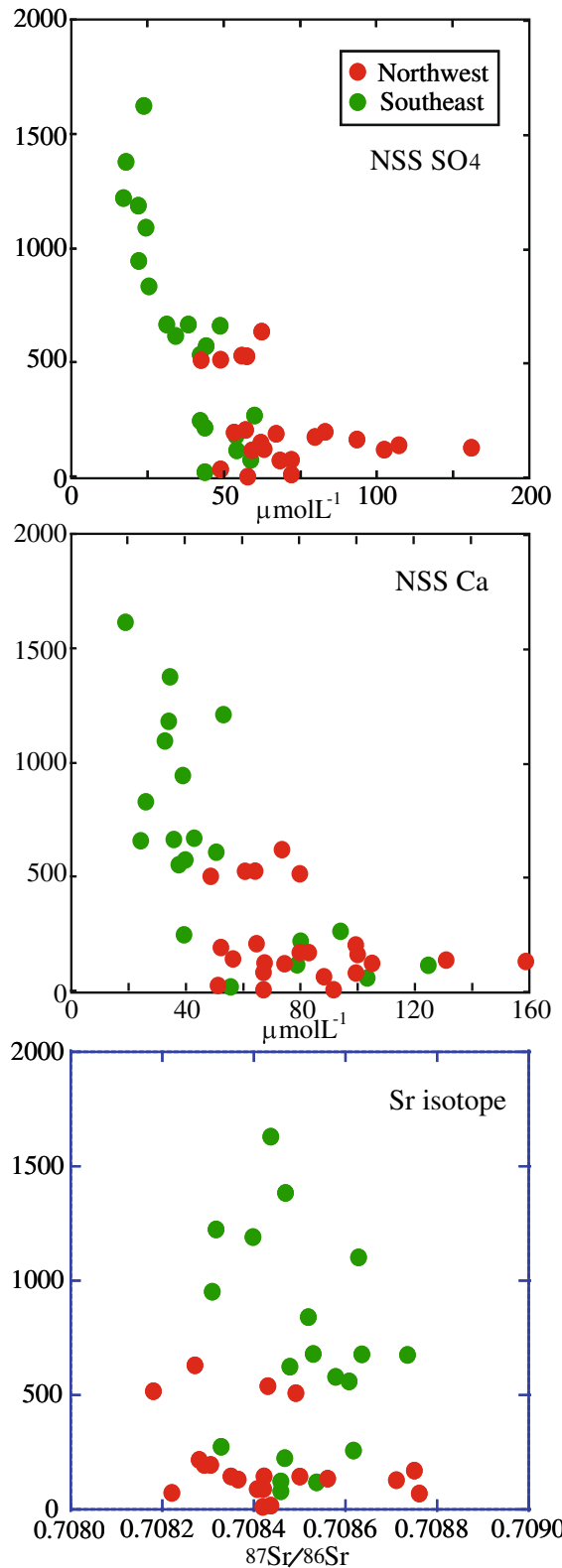

Fig. 5 Altitudinal change of concentration of $\mathrm{NSS} \mathrm{SO}_{4}$ (top), NSS Ca (middle), and ${ }^{87} \mathrm{Sr} /{ }^{86} \mathrm{Sr}$ ratios (bottom) of streamwater in the granite watershed between the northwestern and southeastern sides

constant ratios of dissolved cations to $\mathrm{Cl}$ in Yakushima streamwater indicate that the concentrations of the individual cations derived from bedrock through chemical weathering increase at a relatively constant rate with decreases in the sea salt component derived through the atmosphere. 
If all $\mathrm{Cl}$ in the Yakushima streamwater is derived from a sea salt component dissolved in rainwater and/ or sea spray, and if the uptake of elements by vegetation is negligible, then the proportion of these elements in the streamwater that is derived from rainwater $\left(f_{\text {rain }}\right)$ can be calculated for a dissolved cation $(X$, representing $\mathrm{Na}, \mathrm{K}, \mathrm{Ca}$, and $\mathrm{Mg}$ ) by using the following equation:

$f_{\text {rain }}=(X / \mathrm{Cl})_{\text {rainwater }} /(X / \mathrm{Cl})_{\text {streamwater }}$

Using the annual average of the compositions of dissolved ions in Yakushima rainwater (Table 2), we calculated that $32 \%$ of the $\mathrm{Ca}$ and $36 \%$ of the $\mathrm{K}$ in the streamwater of watersheds with granitic bedrock were derived from precipitation, whereas the rainwater contributed $81 \%$ of the $\mathrm{Na}$ and $83 \%$ of the Mg. In other words, two thirds of the $\mathrm{Ca}$ and $\mathrm{K}$ in the streamwater originated from weathering of the granites and Kumage sedimentary rock. The average order of dominance of the cations in streamwater contributed by the granite BDC was $\mathrm{Na}\left(52.2 \mu \mathrm{molL} \mathrm{L}^{-1}\right)>\mathrm{Ca}(24.7 \mu \mathrm{mol}$ $\left.\mathrm{L}^{-1}\right)>\mathrm{K}\left(10.8 \mu \mathrm{molL}^{-1}\right)>\mathrm{Mg}\left(5.4 \mu \mathrm{molL}^{-1}\right)$. The order for the Kumage BDC was $\mathrm{Na}\left(54.7 \mu \mathrm{molL}^{-1}\right)>\mathrm{Ca}$ $\left(24.1 \mu \mathrm{molL}{ }^{-1}\right)>\mathrm{K}\left(15.2 \mu \mathrm{molL} L^{-1}\right)>\mathrm{Mg}(12.8 \mu \mathrm{mol}$ $\mathrm{L}^{-1}$; Table 2).

\subsubsection{Effects of Chemical Weathering of Granite on the Yakushima Streamwater}

As mentioned above, the chemical composition of the streamwater did not differ significantly between watersheds with granite bedrock and Kumage sedimentary bedrock (Table 2). This result can be ascribed to the similarity of the dissolved ions in the BDC for both bedrocks. For example, the average molar ratios of $\mathrm{Ca}$, $\mathrm{K}$, and $\mathrm{Mg}$ to $\mathrm{Na}$ in the streamwater for the granite $\operatorname{BDC}(0.47,0.21$, and 0.10$)$ were generally similar to those in the streamwater for the Kumage BDC (0.44, 0.28 , and 0.23 ). On the other hand, Table 3 shows corresponding ratios of 0.32 for $\mathrm{Ca} / \mathrm{Na}, 0.91$ for $\mathrm{K} / \mathrm{Na}$, and 0.19 for $\mathrm{Mg} / \mathrm{Na}$ from the granites, versus 0.32 , 0.83 , and 0.62 , respectively, for the Kumage sedimentary rock, showing that both rocks have similar $\mathrm{Ca} / \mathrm{Na}$ and $\mathrm{K} / \mathrm{Na}$ ratios but very different $\mathrm{Mg} / \mathrm{Na}$ ratios.

This difference can be ascribed to the chemical weathering process because the cation compositions differed remarkably between the BDC in streamwater and in the bedrock. One notable feature is that the molar $\mathrm{Ca} / \mathrm{K}$ ratios of the granite $\mathrm{BDC}(2.28)$ and of the Kumage BDC (1.58) were much higher than those of the corresponding rocks $(0.39$ and 0.61 , respectively). This contrast is attributable to the higher susceptibility of $\mathrm{Ca}$ minerals than $\mathrm{K}$ minerals to chemical weathering; thus, the bedrock would become progressively depleted of $\mathrm{Ca}$ at a faster rate than $\mathrm{K}$.

The mineralogical composition of the granite is more distinct than that of the sandstone and shale in the Kumage sedimentary rock. The major cations in the streamwater of the granite BDC can be largely ascribed to the dissolution of potassium feldspar for $\mathrm{K}$ and $\mathrm{Na}$, of plagioclase for $\mathrm{Ca}$ and $\mathrm{Na}$, and of biotite for $\mathrm{K}$ and $\mathrm{Mg}$. Potassium is the dominant cation in the Yakushima granite but is present at a lower level in the granite BDC. As the modal composition of $\mathrm{K}$ feldspar and plagioclase in the granite is around $30 \%$ respectively, whereas that of biotite is about $5 \%$ (Anma et al. 1998), this result shows that the potassium feldspar does not supply enough $\mathrm{K}$ into water.

In addition to plagioclase, the $\mathrm{Ca}$ in granite is substituted as accessory minerals such as apatite and carbonates. The average $\mathrm{Ca}$ content of apatite in the Yakushima granite is estimated to be $1,180 \mathrm{ppm}$ on the basis of the $\mathrm{P}$ content (an average of $547 \mathrm{ppm}$; Table 3). Although previous studies have not described the presence of carbonates in the Yakushima granite, White et al. (2005) showed that most granite in the world contains at least some carbonates, with an average modal ratio of $0.25 \%$. If the Yakushima granite contains $0.25 \%$ carbonates, as estimated by White et al. (2005), the Ca concentration in the carbonates would be $0.1 \mathrm{wt} \%$. On the other hand, the mean $\mathrm{Ca}$ content of the Yakushima granite was $1.43 \mathrm{wt} \%$ (Table 3). Accordingly, the total amount of Ca derived from apatite and carbonates in the Yakushima granite would be less than $15 \%$. According to Nakano et al. (2001c), the soils on Yakushima are depleted in $\mathrm{Ca}$ compared with the original granite parent material, with the depletion reaching more than $90 \%$ in the $\mathrm{C}$ horizon, which is composed primarily of weathered granite. This result indicates that the $\mathrm{Ca}$ in the granite BDC can be attributed mainly to weathering of the plagioclase.

Although plagioclase and potassium feldspar are two mineral sources of $\mathrm{Na}$ in the streamwater, the average molar ratio of $\mathrm{K}$ to $\mathrm{Ca}$ in the granite $\mathrm{BDC}$ of streamwater (0.44) is very low compared with that in the granite (2.97), indicating that the major source of 


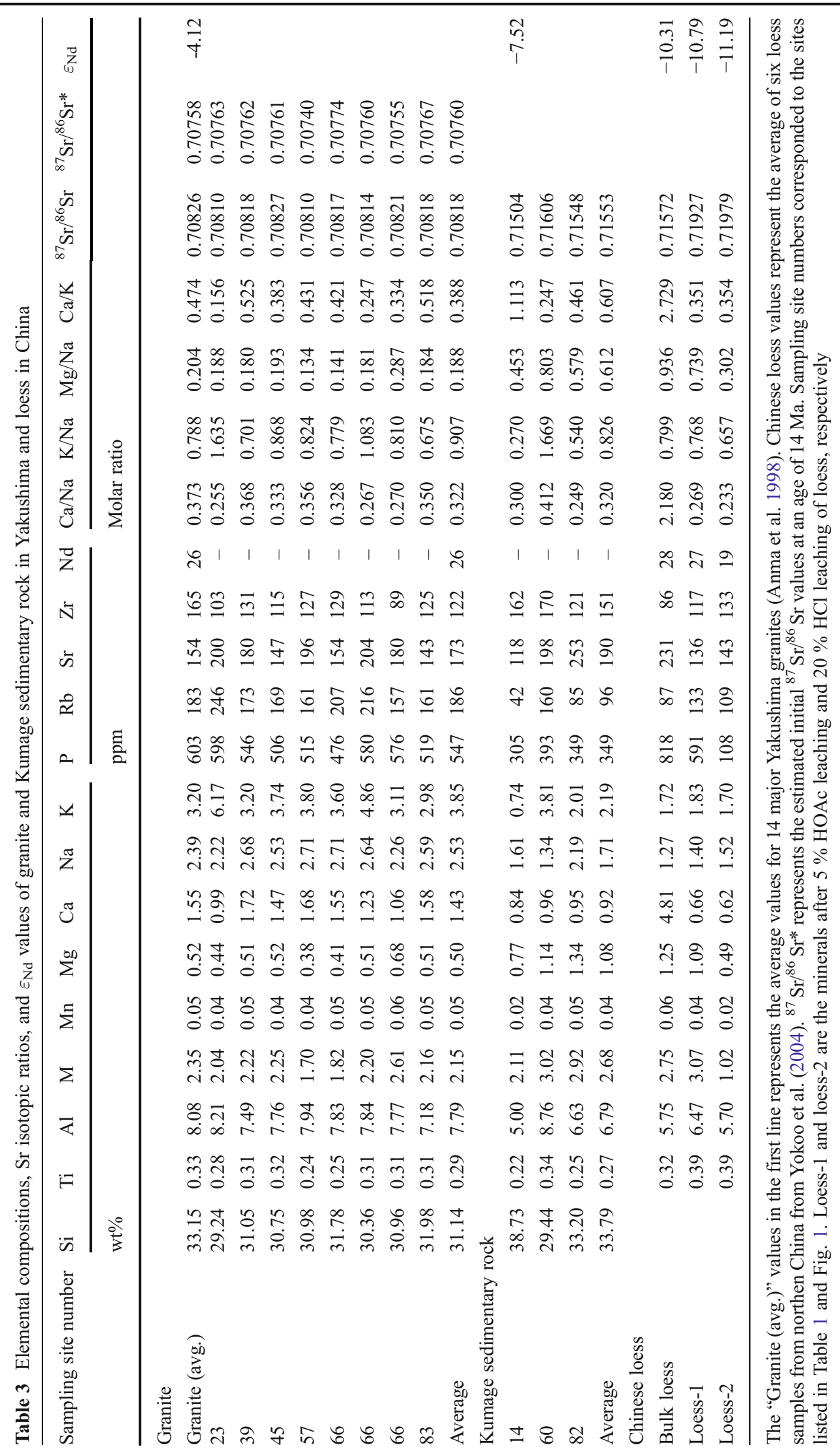


$\mathrm{Na}$ in the streamwater is Ca-containing plagioclase rather than potassium feldspar. On the other hand, the average molar $\mathrm{Ca} / \mathrm{Na}$ ratio of granite $\mathrm{BDC}$ in streamwater (0.47) is close to that of the bulk granite (0.32) and plagioclase (0.2 to 1.0; Anma et al. 1998). These data suggest that plagioclase is selectively weathered and releases $\mathrm{Ca}$ and $\mathrm{Na}$ into the water (Berner and Berner 1987). The average molar $\mathrm{Mg} / \mathrm{Na}$ ratio in the granite $\mathrm{BDC}(0.10)$ is lower than the average molar $\mathrm{Ca} / \mathrm{Na}$ and $\mathrm{K} / \mathrm{Na}$ ratios $(0.32$ and $0.91)$. This result is consistent with the modal ratio of biotite in the granite, which is less than 0.05 , and little $\mathrm{Mg}$ moves into secondary minerals (e.g., chlorite, vermiculite) during the chemical weathering of biotite (Nakano et al. 1991).

\subsubsection{Fraction of Rain-Derived Sr in the Yakushima Streamwater}

Similarly to the other cations, $\mathrm{Sr}$ in the streamwater is derived from both rainwater and the watershed's bedrock. We used the following equation for the Sr isotope ratio to determine the proportions of the $\mathrm{Sr}$ derived from rainwater and BDC:

$$
\begin{aligned}
\left({ }^{87} \mathrm{Sr} /{ }^{86} \mathrm{Sr}\right)_{\text {streamwater }} & =f_{\mathrm{Sr}-\text { rain }}\left({ }^{87} \mathrm{Sr} /{ }^{86} \mathrm{Sr}\right)_{\text {rainwater }} \\
& +\left(1-f_{\mathrm{Sr}-\text { rain }}\right)\left({ }^{87} \mathrm{Sr} /{ }^{86} \mathrm{Sr}\right)_{\mathrm{BDC}}
\end{aligned}
$$

where $f_{\text {Sr-rain }}$ is the ratio of the $\mathrm{Sr}$ in rainwater to that in streamwater.

The ${ }^{87} \mathrm{Sr} /{ }^{86} \mathrm{Sr}$ ratio in streamwater in the granite watersheds ranges from 0.70818 to 0.70876 , whereas that in the Kumage sedimentary rock watersheds ranges from 0.71023 to 0.71345 (Fig. 4). This difference corresponds to the difference in the ratios for granite $(0.70810$ to 0.70827$)$ and for the Kumage sedimentary rocks $(0.71504$ to 0.71606$)$, indicating that part of the $\mathrm{Sr}$ in streamwater is derived from weathering of the bedrock in the watershed. Nevertheless, there is no altitudinal change in the ${ }^{87} \mathrm{Sr} /{ }^{86} \mathrm{Sr}$ ratio in Yakushima streamwater in the granite watershed (Fig. 4). This result suggests that the contribution of $\mathrm{Sr}$ from granite to the streamwater is close to that from the atmosphere. In contrast, Nakano et al. (2000) have shown that rain is the dominant source of seawater-derived $\mathrm{Sr}$ on Yakushima, with a uniform ${ }^{87} \mathrm{Sr} /{ }^{86} \mathrm{Sr}$ value of 0.70918 (Faure and
Mensing 2005). However, it is difficult to determine the ${ }^{87} \mathrm{Sr} /{ }^{86} \mathrm{Sr}$ ratios for granite $\mathrm{BDC}$ and Kumage $\mathrm{BDC}$, as these ratios are a function of factors such as the degree of chemical weathering, the $\mathrm{Sr}$ contents and ${ }^{87} \mathrm{Sr} /{ }^{86} \mathrm{Sr}$ ratios of the primary minerals, and the $\mathrm{Sr}$ content of the secondary minerals.

The initial ${ }^{87} \mathrm{Sr} /{ }^{86} \mathrm{Sr}$ ratio of the Yakushima granites at a formation age of $14 \mathrm{Ma}$ was calculated to average 0.70760 (Table 3). The ${ }^{87} \mathrm{Sr} /{ }^{86} \mathrm{Sr}$ ratio of plagioclase and apatite in the granite was also estimated to be around 0.70760 , since radiogenic $\mathrm{Sr}$ released by the decay of ${ }^{87} \mathrm{Rb}$ is negligible in these minerals, which generally have a low $\mathrm{Rb} / \mathrm{Sr}$ ratio, and because of the relatively young age of the Yakushima granite. If the ${ }^{87} \mathrm{Sr} /{ }^{86} \mathrm{Sr}$ ratio of granite $\mathrm{BDC}$ in the streamwater is identical to that of the bulk granite or plagioclase (plus apatite and carbonates), the value of $f_{\text {Sr-rain }}$ can be calculated as 0.28 or 0.53 , respectively. The former value is very close to the value of the rainwater proportion for $\mathrm{Ca}\left(f_{\text {Ca-rain }}=0.32\right)$, which was determined by using $\mathrm{Cl}$ (as described in Section 3.1.3), but the plagioclase-based value is higher.

To determine the value of $f_{\text {Sr-rain }}$ on the basis of the method using $\mathrm{Cl}$, we estimated the $\mathrm{Sr} / \mathrm{Cl}$ ratio of rainwater by using the following equation:

$$
(\mathrm{Sr} / \mathrm{Cl})_{\text {rain }}=\left(\mathrm{Sr}_{\text {sea-salt }} / \mathrm{Cl}_{\text {rain }}\right)+\left(\mathrm{Sr}_{\mathrm{NSS}} / \mathrm{Cl}_{\text {rain }}\right)
$$

This equation can be expressed by using the proportion of NSS Sr in the rain $\left(f_{\mathrm{NSSSr}}\right.$-rain $)$, as follows:

$$
\begin{aligned}
(\mathrm{Sr} / \mathrm{Cl})_{\text {rain }} & =(\mathrm{Sr} / \mathrm{Cl})_{\text {seawater }} \\
& +\left[f_{\mathrm{NSSSr}-\text { rain }} /\left(1-f_{\mathrm{NSSSr}-\text { rain }}\right)\right](\mathrm{Sr} / \mathrm{Cl})_{\text {seawater }}
\end{aligned}
$$

Although there is no report on the Sr content of Yakushima rain, the good correlation between the concentrations of $\mathrm{Sr}$ and $\mathrm{Ca}$ in the rain $\left(r^{2}=0.88\right)$ at five sites in Japan indicates that it is possible to estimate the value of $f_{\mathrm{NSS}}$ Sr-rain by using the relationship between NSS $\mathrm{Sr} / \mathrm{Sr}$ and NSS $\mathrm{Ca} / \mathrm{Ca}$, which was reported by Nakano et al. (2006). As the average NSS $\mathrm{Ca} / \mathrm{Ca}$ (weight) of the Yakushima rain was reported to be 0.6 (Nakano et al. 2000), the $f_{\mathrm{NSS} \text { Sr-rain }}$ can be estimated to be 0.15 using Fig. 4 of Nakano et al. (2006). Accordingly, the molar ratio of $\mathrm{Sr} / \mathrm{Cl}$ for Yakushima's rain can be estimated to be 0.00019 by using Eq. 4 and the concentrations of $\mathrm{Sr}$ and $\mathrm{Cl}$ in seawater (Berner and Berner 1987). Because the $\mathrm{Sr} / \mathrm{Cl}$ 
value in Yakushima's streamwater (mean molar ratio for granite and sedimentary bedrock $=0.00057$; Table 2) does not differ greatly between the granite and Kumage sedimentary rock watersheds, the rainwater proportion for $\mathrm{Sr}$ in the streamwater can be calculated to be 0.33 from Eq. 1. This value is close to the value of 0.28 obtained from Eq. 2 when the ${ }^{87} \mathrm{Sr} /{ }^{86} \mathrm{Sr}$ ratio of granite BDC is assumed to be the same as that of bulk granite rather than the result of selective leaching of cations from plagioclase and apatite. This result is consistent with that of Flanklyn et al. (1991), who reported that the ${ }^{87} \mathrm{Sr} /{ }^{86} \mathrm{Sr}$ ratio of shallow groundwater in Canada was identical to that of granite within the same watershed. However, the $\mathrm{Sr}$ isotopic coincidence between granite BDC and bulk granite is not well explained at present, and possible reasons for this coincidence must be examined in a future study.

The major source of $\mathrm{Sr}$ in the water of watersheds underlain by igneous rock is attributed to plagioclase with accessory apatite and carbonates because of its high Sr content and its high susceptibility to chemical weathering. Nevertheless, the presence of bedrockderived $\mathrm{K}(64 \%)$ and $\mathrm{Mg}(17 \%)$ in the Yakushima streamwater indicates that potassium feldspar and biotite, despite their small $\mathrm{Sr}$ contributions, can still supply enough $\mathrm{Sr}$ into the streamwater to increase its ${ }^{87} \mathrm{Sr} /{ }^{86} \mathrm{Sr}$ ratio. Thus, the contributions of rainwater and watershed bedrock to the streamwater can be evaluated by comparing their elemental compositions and their ${ }^{87} \mathrm{Sr} /{ }^{86} \mathrm{Sr}$ ratios.

Figure 5 shows that the ${ }^{87} \mathrm{Sr} /{ }^{86} \mathrm{Sr}$ ratio of streamwater in the granite watershed does not differ significantly between the northwestern and southeastern sides, indicating that the chemical weathering of granite is not always intense in the northwestern side where the deposition of $\mathrm{NSS} \mathrm{SO}_{4}$ is high. This result is consistent with the above-mentioned view that an-

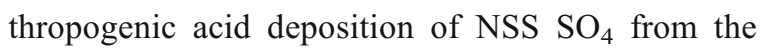
Asian continent is not a major factor for the altitudinal decrease of $\mathrm{pH}$ in Yakushima streamwater. Residence time of rainwater would also become short with elevation, which leads to the generation of streamwater with low $\mathrm{pH}$ and dissolved ions. In order to evaluate the impact of acidic rain on Yakushima's aquatic system, it will be necessary to monitor rainfall $\mathrm{pH}$ and the quality of streamwater at several sites with different elevations; currently, no such data are available for Yakushima Island.
3.2 Soil-Vegetation System

\subsubsection{Contribution of Atmospheric Sr to the Soil- Vegetation System}

Similar to the situations with other elements, the $\mathrm{Sr}$ in terrestrial plants is ultimately derived from the atmosphere and the bedrock. In contrast with the ratios of many stable isotopes such as $\mathrm{Si}$ and $\mathrm{Ca}$, the ${ }^{87} \mathrm{Sr} /{ }^{86} \mathrm{Sr}$ ratio in the TIMS analysis was determined after correcting for mass fractionation (Faure and Mensing 2005), so the plant $\mathrm{Sr}$ should have the same ${ }^{87} \mathrm{Sr} /{ }^{86} \mathrm{Sr}$ ratio as the ratio in the ambient soil solution. Given the different $\mathrm{Sr}$ isotope ratios in the two sources, it is possible to estimate their relative contribution to $\mathrm{Sr}$ in plants by comparing the variation in ${ }^{87} \mathrm{Sr} /{ }^{86} \mathrm{Sr}$ ratios and using the calculation method proposed by Graustein (1988). This method approximates the values as follows:

$$
\begin{aligned}
\left({ }^{87} \mathrm{Sr} /{ }^{86} \mathrm{Sr}\right)_{\text {plant }}= & f_{\mathrm{Sr} \text {-rain }}\left({ }^{87} \mathrm{Sr} /{ }^{86} \mathrm{Sr}\right)_{\text {rainwater }} \\
& +\left(1-f_{\text {Sr-rain }}\right)\left({ }^{87} \mathrm{Sr} /{ }^{86} \mathrm{Sr}\right)_{\mathrm{BDC}}
\end{aligned}
$$

Graustein (1988) estimated that about 60 to $80 \%$ of the $\mathrm{Sr}$ in spruce and aspen in the Tesuque watershed of New Mexico is derived from precipitation. Likewise, Miller et al. (1993) reported that about $53 \%$ of the $\mathrm{Sr}$ in the vegetation in a forest ecosystem in the Adirondack Mountains of New York was of atmospheric origin.

The ${ }^{87} \mathrm{Sr} /{ }^{86} \mathrm{Sr}$ ratios for terrestrial plants on Yakushima depend on the underlying bedrock. They ranged from 0.70861 to 0.70912 (mean $=0.70892)$ on granitic bedrock and from 0.70918 to 0.70935 (mean= 0.70925 ) on the Kumage sedimentary bedrock (Nakano et al. 2000). On Yakushima, the ${ }^{87} \mathrm{Sr} /{ }^{86} \mathrm{Sr}$ ratio in rainwater is close to that in seawater (Nakano et al. 2000). On the other hand, it is reasonable to assume that the chemical composition and $\mathrm{Sr}$ isotope ratio of $\mathrm{BDC}$ in soil water are similar to those in streamwater; in the granite watersheds, the ${ }^{87} \mathrm{Sr} /{ }^{86} \mathrm{Sr}$ ratio of $\mathrm{BDC}$ can be represented by the average ratio for Yakushima granite (0.70818). If these assumptions are valid, the proportion of rain-derived $\mathrm{Sr}$ in the plants on granite substrates would range from 43 to $94 \%$ (mean $=74 \%)$, indicating a large contribution of rain-derived $\mathrm{Sr}$ in Yakushima's plants on a granite substrate. 
The ${ }^{87} \mathrm{Sr} /{ }^{86} \mathrm{Sr}$ ratio of Kumage BDC is not easily evaluated compared with that of the granite BDC, because the $\mathrm{Sr}$ contents and ${ }^{87} \mathrm{Sr} /{ }^{86} \mathrm{Sr}$ ratios of the constituent minerals in the Kumage sedimentary rocks are more heterogeneous. However, if the $f_{\mathrm{Sr}}$ rain in streamwater of the Kumage sedimentary rock watersheds is the same as that in the granite watersheds (33\%), the ${ }^{87} \mathrm{Sr} /{ }^{86} \mathrm{Sr}$ ratio of Kumage BDC can be calculated as 0.71368 by using Eq. 2. By substituting this value into Eq. 5, the proportion of rain-derived $\mathrm{Sr}$ in the plants growing on the Kumage sedimentary substrate can be calculated to be more than $96 \%$. This value increases to $98 \%$ if the Kumage BDC has the average ${ }^{87} \mathrm{Sr} /{ }^{86} \mathrm{Sr}$ ratio of the Kumage sedimentary rocks (0.71552). The dominance of rainwater sources of $\mathrm{Sr}$ in the plants growing in the Kumage sedimentary rock watersheds can likely be ascribed to the fact that vegetation in these watersheds is affected strongly by sea salt particles, as these sites are found mainly at lower elevations near the coast. Thus, plants on Yakushima are more enriched in rainwater-derived $\mathrm{Sr}$ of sea salt origin than streamwater, regardless of the bedrock type.

Table 4 shows the soil chemical composition, ${ }^{87} \mathrm{Sr} /{ }^{86} \mathrm{Sr}$ ratio of plants, ${ }^{87} \mathrm{Sr} /{ }^{86} \mathrm{Sr}$ ratio, and $\varepsilon_{\mathrm{Nd}}$ value of soils at the Yotsuse site, which overlies a granite substrate. At this site, the three plant species that we sampled had similar ${ }^{87} \mathrm{Sr} /{ }^{86} \mathrm{Sr}$ ratios $(0.70911$ for the leaves of Japanese cedar, 0.70913 for plants, and 0.70915 for the leaves of Japanese red pine). These values were close to the ${ }^{87} \mathrm{Sr} /{ }^{86} \mathrm{Sr}$ ratio of seawater. From Eq. 5, we can calculate that 93 to $97 \%$ of the $\mathrm{Sr}$ in the Yotsuse plants was derived from sea salt Sr. It is notable that the ${ }^{87} \mathrm{Sr} /{ }^{86} \mathrm{Sr}$ ratio in the plants is close to that of the exchangeable soil pool at different depths (which ranges from 0.70911 to 0.70920 ), with the exception of the lower $\mathrm{C}$ horizon, where the ${ }^{87} \mathrm{Sr} /{ }^{86} \mathrm{Sr}$ ratio (0.70884) is close to that of the underlying granite (Fig. 6). Another notable feature is that the ${ }^{87} \mathrm{Sr} /{ }^{86} \mathrm{Sr}$ ratio of the bulk soil at the Yotsuse site decreases from 0.71552 near the surface to 0.70908 with increasing depth. This ratio is generally higher and more variable than the ${ }^{87} \mathrm{Sr} /{ }^{86} \mathrm{Sr}$ ratios in the plants and in the exchangeable soil pool. The relationship between the $\mathrm{Sr}$ isotope ratios in the plants, soil, and exchangeable soil pool is consistent with the view that $\mathrm{Sr}$ and other nutrients in Yakushima's plants are affected strongly by rainwater and are exchanged with the exchangeable soil pool rather than with the associated soil minerals.

\subsubsection{Asian Dust Minerals in the Soil}

The depth profile of elements in the soil column at Yotsuse differed among the elements (Table 4, Fig. 6). $\mathrm{Ti}$ and $\mathrm{Zr}$ are assumed to be immobile in the soil environment during the weathering process (Kirkwood and Nesbitt 1991). The degree of enrichment and depletion of element $x$ in the soil at this site, termed $f x$, was calculated by using the following equation:

$f x=\left(W_{\text {soil }}^{x} / W_{\text {soil }}^{\mathrm{Ti}}\right) /\left(W_{\mathrm{gr}}^{x} / W_{\mathrm{gr}}^{\mathrm{Ti}}\right)$

where $W_{\text {soil }}^{x}$ and $W_{\text {soil }}^{\mathrm{Ti}}$ are the concentrations of $x$ and $\mathrm{Ti}$, respectively, in the soil and $W_{\mathrm{gr}}^{x}$ and $W_{\mathrm{gr}}^{\mathrm{Ti}}$ are the corresponding concentrations in granite.

Most elements except Fe were depleted in the soil column, but the depletion pattern depended on the element (Fig. 6). $\mathrm{Ca}, \mathrm{Na}, \mathrm{P}$, and $\mathrm{Sr}$ were depleted at all depths in the soil compared with their values in the granite parent material. The $\mathrm{Ca}$ content in the $\mathrm{A}$ and $\mathrm{B}$ horizons declined to less than $10 \%$ of the value in the parent material, and the $\mathrm{Na}, \mathrm{Sr}$, and $\mathrm{P}$ contents in the $\mathrm{A}$ and B horizons declined to less than $20 \%$ of the level in the parent material. On the other hand, the degree of depletion was less than $50 \%$ for $\mathrm{K}, \mathrm{Mg}, \mathrm{Mn}$, and $\mathrm{Rb}$, and the magnitude of the depletion decreased with increasing depth in the $\mathrm{C}$ horizon owing to the weak degree of chemical weathering of minerals containing these elements at these depths. This pattern shows that plagioclase and small amounts of apatite and carbonates (White et al. 2005; Hartmann 2009) are more intensely weathered than potassium feldspar and biotite.

This result is consistent with the results from soil columns at two other sites on Yakushima (ShirataniUnsuikyo and Shin-Takatsuka; Fig. 1). At all sites, the depletion of $\mathrm{Ca}, \mathrm{Na}, \mathrm{P}$, and $\mathrm{Sr}$ in the soil compared with the levels in the original granite was large (generally $>50 \%$ ), whereas the depletion was weak (10 to $50 \%$ ) for $\mathrm{K}, \mathrm{Si}, \mathrm{Mg}, \mathrm{Mn}$, and $\mathrm{Rb}$. The depletion was largest for $\mathrm{Ca}$, reaching more than $95 \%$ in the $\mathrm{B}$ horizon at the Yotsuse and Shiratani-Unsuikyo sites. Soils in the $\mathrm{C}$ horizon are composed of primary and secondary minerals, and the original granite texture is well preserved. Accordingly, the depth variation of elements in the $\mathrm{C}$ horizon can be ascribed to chemical weathering, whereas the variations in the $\mathrm{A}$ and $\mathrm{B}$ horizons can likely be ascribed to the presence of organic matter and exotic materials in addition to the substrate materials. 


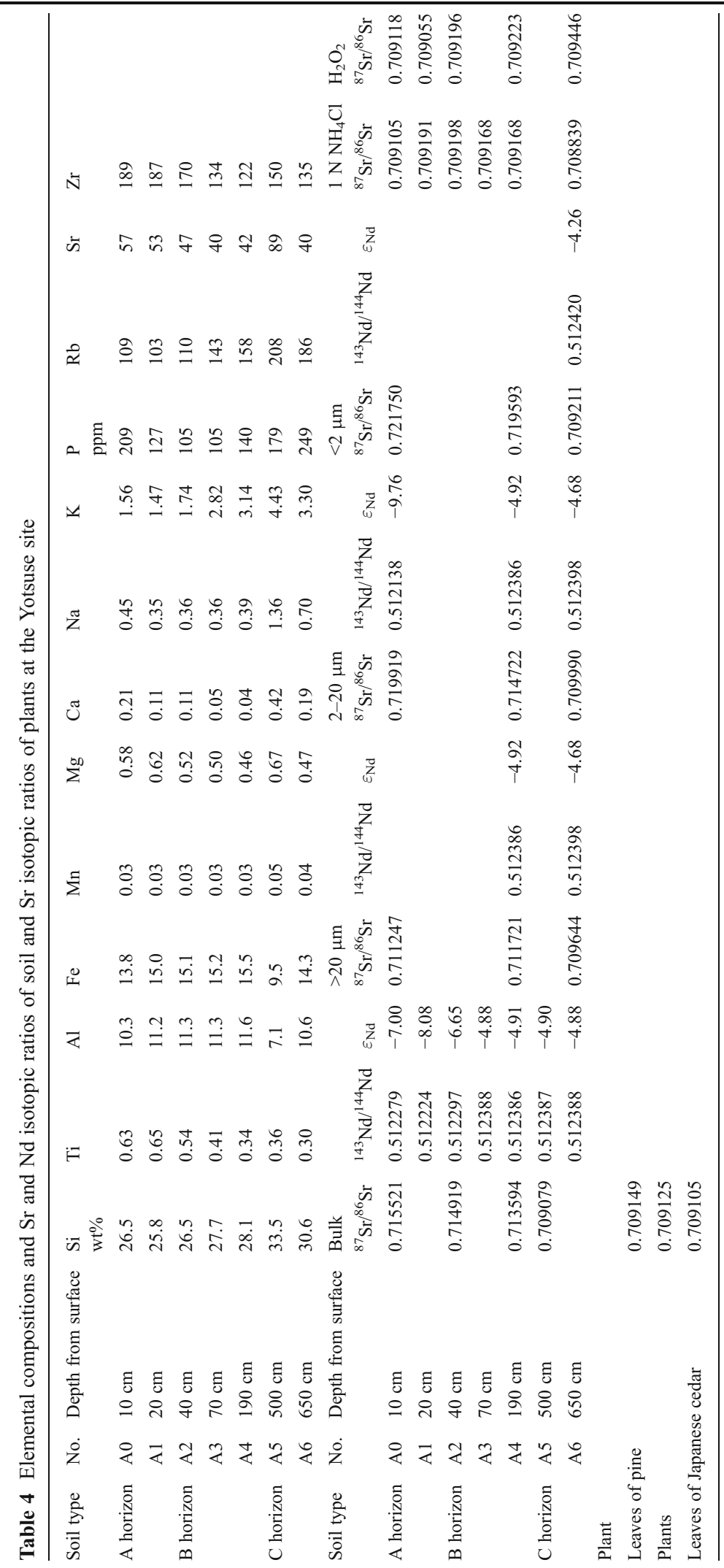




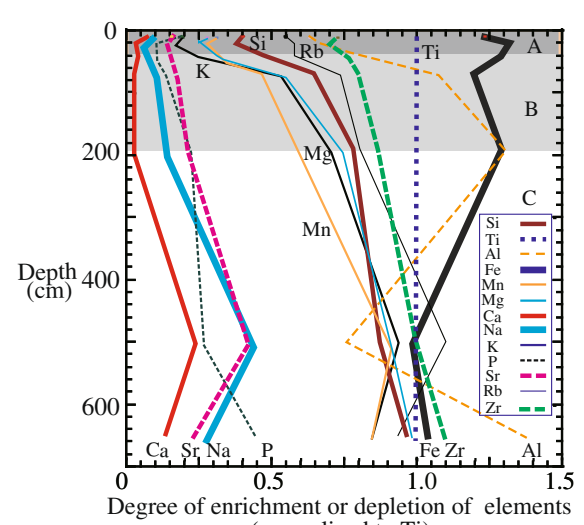

(normalized to $\mathrm{Ti}$ )
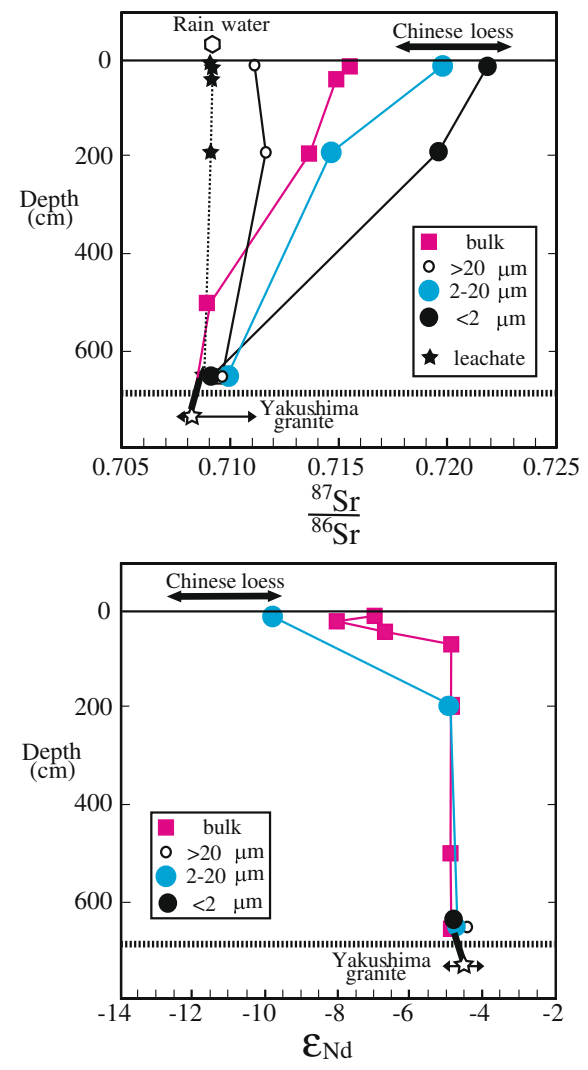

Fig. 6 Top: profiles of the degree of enrichment and depletion of the soil elements (relative to a normalized value of 1.0 in the granite parent material, represented by the dashed line) as a function of depth in the soil at the Yotsuse site. Middle: profiles of the ${ }^{87} \mathrm{Sr} /{ }^{86} \mathrm{Sr}$ ratio and (bottom) of the $\varepsilon_{\mathrm{Nd}}$ values in the soil (for three particle size classes) as a function of depth and in the soil leachate. The $\mathrm{C}$ horizon is composed of weathered granite

The ${ }^{87} \mathrm{Sr} /{ }^{86} \mathrm{Sr}$ ratio and $\varepsilon_{\mathrm{Nd}}$ values of the $\mathrm{C}$ horizon at Yotsuse were independent of the particle size, and ranged from 0.70908 in the upper $\mathrm{C}$ horizon to 0.70999 and from -4.90 to -4.26 , respectively. These $\varepsilon_{\mathrm{Nd}}$ values are indistinguishable from those of the Yakushima main granite ( -5.3 to -4.1 ; Anma et al. 1998), whereas the ${ }^{87} \mathrm{Sr} /{ }^{86} \mathrm{Sr}$ ratios in the $\mathrm{C}$ horizon are higher than those of the Yakushima main granite (0.70818). This increased ${ }^{87} \mathrm{Sr} /{ }^{86} \mathrm{Sr}$ in the $\mathrm{C}$ horizon seems attributable to the enrichment by potassium feldspar, muscovite, and secondary minerals from biotite with high ${ }^{87} \mathrm{Sr} /{ }^{86} \mathrm{Sr}$ ratios. One notable feature is that the ${ }^{87} \mathrm{Sr} /{ }^{86} \mathrm{Sr}$ ratio in the bulk soil at Yotsuse tends to increase towards the surface, moving from the $\mathrm{B}$ horizon to the A horizon, whereas the $\varepsilon_{\mathrm{Nd}}$ value tends to decrease. This result indicates that the Yotsuse soil contains minerals that did not originate in the parent material, with a high ${ }^{87} \mathrm{Sr} /{ }^{86} \mathrm{Sr}$ ratio and a low $\varepsilon_{\mathrm{Nd}}$ value, and their contribution increases toward the surface of the soil column.

China's Central Loess Plateau is a major depositional area for dust minerals emitted from the upwind desert areas of northern China and southern Mongolia. Loess in this region is composed of minerals produced by wind erosion and by evaporation (mainly calcite but also anhydrites and halides) that can be dissolved by water and acetic acid, phosphates and Mg-containing chlorites that can be dissolved by hydrochloric acid $(\mathrm{HCl})$, and silicates and small amounts of oxides that resist chemical weathering. According to Yokoo et al. (2004), these minerals have distinct ${ }^{87} \mathrm{Sr} /{ }^{86} \mathrm{Sr}$ ratios, with values of $0.7111 \pm 0.0004$ (mean \pm SD) for evaporite minerals, $0.7141 \pm 0.0004$ for phosphates and chlorites, and $0.7195 \pm 0.0010$ for silicates, whereas silicates have $\mathrm{Nd}$ isotope ratios similar to those of the bulk loess. According to Takahashi et al. (2001), the $\mathrm{pH}\left(\mathrm{H}_{2} \mathrm{O}\right)$ value of forest surface soil at 1,034 sites in Japan ranged from 3.5 to 8.1 , with a median of 5.1. Because the first two types of minerals are not stable in Japan's acidic soils, it is possible that the acid-resistant silicate minerals from the Central Loess Plateau are still present in the soil of Yakushima Island.

Another notable feature is that the ${ }^{87} \mathrm{Sr} /{ }^{86} \mathrm{Sr}$ ratios and $\varepsilon_{\mathrm{Nd}}$ values of the Yotsuse soil depended on the particle size (Table 4, Fig. 6). In the A and B horizons, the ${ }^{87} \mathrm{Sr} /{ }^{86} \mathrm{Sr}$ ratio increases from 0.71125 to 0.71172 in the coarsest particles $(>20 \mu \mathrm{m})$ to $0.71959-0.72175$ in the finest particles $(<2 \mu \mathrm{m})$. The particles $>20 \mu \mathrm{m}$ have a relatively constant ${ }^{87} \mathrm{Sr} /{ }^{86} \mathrm{Sr}$ ratio, irrespective of depth, indicating that they are derived from the granite substrate. The ${ }^{87} \mathrm{Sr} /{ }^{86} \mathrm{Sr}$ ratio $(0.71992-0.72175)$ and $\varepsilon_{\mathrm{Nd}}$ value $(-9.76)$ of the two fine-grained fractions (220 and $<2 \mu \mathrm{m})$ in the upper A horizon are similar to those of acid-insoluble minerals in the loess of the 
Central Loess Plateau (average, 0.72063 and -12.5). Because the average diameter of Asian dust particles falling on Japan is about $4 \mu \mathrm{m}$ (Nagoya University 1991), and because larger particles are less likely to be transported over long distances, the contribution of Asian dust would increase with decreasing particle size. The dependence of the $\mathrm{Sr}$ and $\mathrm{Nd}$ isotope ratios on particle size and depth in the Yotsuse soil column strongly suggests that the exotic minerals in the soil originated from silicates present in Asian dust and that the proportion of this foreign dust increases in the upper soil horizons.

We evaluated the granite-derived and dust-derived minerals in the Yotsuse soil by using the concentrations and isotope ratios of $\mathrm{Sr}$ and $\mathrm{Nd}$ in the Yakushima granite and in Chinese loess silicates (Fig. 7). We assumed two different ${ }^{87} \mathrm{Sr} /{ }^{86} \mathrm{Sr}$ ratios and $\varepsilon_{\mathrm{Nd}}$ values for each of these components on the basis of the observed variation for the Chinese loess silicates and for the Yakushima granites and weathered silicates. The $\mathrm{Sr}$ and $\mathrm{Nd}$ contents of the dust minerals were assumed to be 150 and $20 \mathrm{ppm}$, respectively, whereas those of the granite-derived components were assumed to be 30 and 26 ppm, respectively, because the $\mathrm{Sr}$ content of the weathered granite is significantly

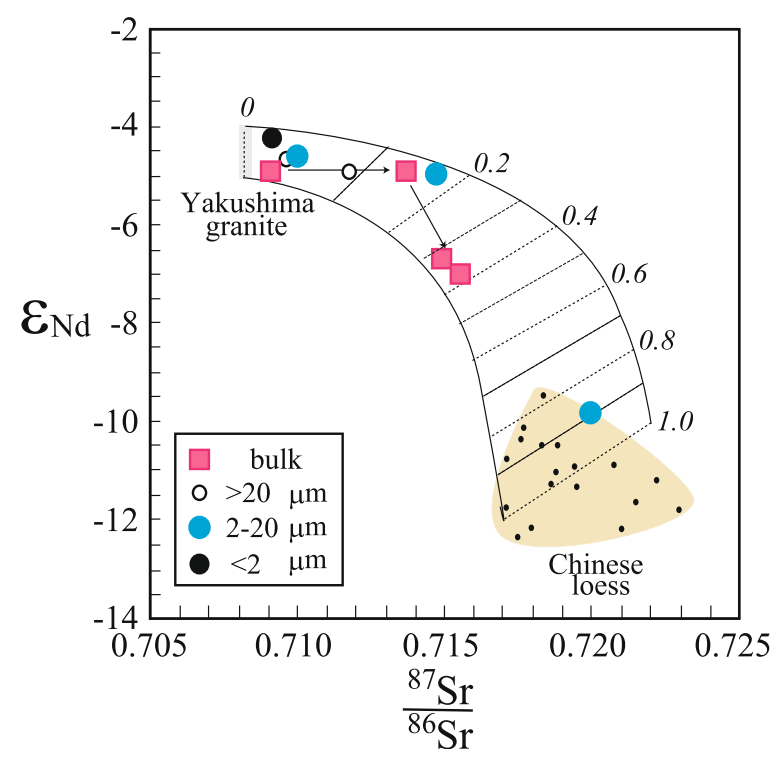

Fig. 7 Plot of ${ }^{87} \mathrm{Sr} /{ }^{86} \mathrm{Sr}$ versus $\varepsilon_{\mathrm{Nd}}$ for soil minerals with three particle sizes and for bulk soil at the Yotsuse site. Data for the Chinese loess are from Nakano et al. (2004) for $\mathrm{HCl}$ residual minerals of surface soils from the Southern Gobi and Central Loess Plateau. Data for the Yakushima granite are those of Anma et al. (1998) lower than that of the granite parent material. On the basis of these assumptions, the ${ }^{87} \mathrm{Sr} /{ }^{86} \mathrm{Sr}$ ratios and $\varepsilon_{\mathrm{Nd}}$ values for the bulk soil and soil minerals with different particle sizes fell within a region between two lines that connect the range of values for the two components. Figure 7 shows that the contribution of Asian dust silicates ranges from 10 to $30 \%$ in the B horizon and $40 \%$ in the A horizon.

The concentration of $\mathrm{Ca}$ in silicates from the Chinese loess is significantly lower than that in the bulk loess, because $\mathrm{Ca}$ in the loess is mainly present in calcium carbonate (Table 3). Because carbonates dissolve easily in acidic rain but loess silicates, which have a low $\mathrm{Ca}$ content, are acid insoluble, it is likely that the Asian dust silicates do not play an important role in the biogeochemical Ca cycle of the Yakushima soil-vegetation system. In contrast, the concentrations of $\mathrm{P}$ in the bulk loess and carbonate-free (acetic acid insoluble) minerals were 818 and 591 ppm, respectively, versus only $108 \mathrm{ppm}$ in the silicate (hydrochloric acid insoluble) minerals (Table 3). Because apatite will dissolve only in an acid solution stronger than that required to dissolve calcium carbonate (Jones et al. 1998), it does not dissolve substantially at the $\mathrm{pH}$ found in acidic rain. Most phosphorus in the Chinese loess $(>80 \%)$ is present as phosphates. Phosphorus in Asian dust plays a dominant role in regulating vegetation growth on base-poor soils that have undergone chemical weathering (Chadwick et al. 1999; Hartmann et al. 2008). It is noteworthy that there are no phosphate minerals in the upper Yotsuse soil. Accordingly, as long as phosphates in the Asian dust are more insoluble in acidic rain than carbonates during their transport through the atmosphere, the phosphates are likely to be dissolved in acidic soil and become the major source of $\mathrm{P}$ in the Yakushima soil-vegetation system.

\subsubsection{Impacts of Atmosphere-Derived Materials on Yakushima Island}

The unique topography of Yakushima, with jagged mountains facing the coast, provides favorable conditions for the formation of clouds from water vapor evaporated from the surrounding seawater and sea salt particles carried into the air by strong winds; this water vapor often condenses to form rain as a result of cooling as it rises along the mountain slopes. This process seems to be the primary control on the 
chemical composition of rainwater and streamwater, which resembles the composition of diluted seawater. It is considered that the water that originates in the sea is not acidic, but is instead somewhat alkaline owing to its high content of sea salts. However, rain is primarily acidic due to carbonic acid formed by dissolving $\mathrm{CO}_{2}$ in the atmosphere. It becomes more acidic by incorporation of anthropogenic SOx and NOx from the Asian continent, resulting in the formation of Yakushima acidic rain with $\mathrm{pH}$ values similar to those measured in other areas of Japan. Large amounts of acidic rain formed in this manner on Yakushima Island are favorable for the generation of acidic soil due to carbonic and organic acids formed in the soil-vegetation system. This geochemical process may accelerate chemical weathering of the Yakushima rocks, leading to leaching of $\mathrm{Ca}, \mathrm{Na}$, and $\mathrm{Sr}$ from plagioclase and of $\mathrm{Ca}$ and $\mathrm{P}$ from apatite, and depletion of these elements in the soil compared with levels in the parent materials.

However, the low concentrations of $\mathrm{Ca}, \mathrm{Sr}$, and $\mathrm{HCO}_{3}$ and the high concentrations of $\mathrm{H}^{+}$in streamwater suggest that chemical weathering (mainly of plagioclase) is not sufficiently fast to compensate for the overload of $\mathrm{H}^{+}$from atmospheric and pedogenetic inputs. Because the rainwater on Yakushima has a low $\mathrm{K}$ content, streamwater $\mathrm{K}$ is predominantly of bedrock origin. Despite its high resistance to chemical weathering, alkali feldspar is a major component of the bedrock and is thus a main source of $\mathrm{K}$ that is leached into the streamwater. Because $\mathrm{Ca}$ and $\mathrm{P}$ are depleted in the soil owing to selective weathering of $\mathrm{Ca}$ containing minerals, both elements in the water are derived mainly from atmospheric deposition. The rain is low in Ca because of the dominant sea salt component. Accordingly, when Asian dust minerals interact with acidic rain before they arrive on Yakushima, calcium carbonate would dissolve into the acidic rain.

Apatite is a trace mineral and is more acid insoluble than carbonates. Because the apatite is enriched in $\mathrm{Ca}$ and $\mathrm{P}$, it is a promising nutrient source for the island's vegetation. Primary production of terrestrial ecosystem is limited by nitrogen availability (Vitousek and Howarth 1991; Schlesinger 1997). Satake et al. (1998) suggested that nitrogen aerosols and gases such as $\mathrm{NOx}$ and $\mathrm{NH}_{4}$ from the Asian continent are potentially limiting nutrients for mountainous forests in Yakushima. The concentration of NOx in the atmosphere of China has recently been increasing owing to the country's rapid economic growth, which has been accompanied by rapidly growing combustion of fossil fuels (Richter et al. 2005). In addition, Asian dust activity has also been increasing since the 1990s over eastern China, Korea, and Japan (Chun et al. 2001; Kurosaki and Mikami 2003). Asian dust is known to play an important role in the rainwater chemistry in northern China (Xu et al. 2009). Accordingly, monitoring the inputs of anthropogenic materials and those of dust minerals from the Asian continent will be indispensable for evaluating their impacts on the soil-vegetation system and on the aquatic ecosystems of Yakushima Island. Understanding these impacts is essential if we are to preserve this important world natural heritage site.

\section{Conclusions}

Yakushima's rainwater contains dissolved cations that are highly enriched in the sea salt component, as well as substantial amounts of anthropogenic $\mathrm{S}$ and $\mathrm{N}$ compounds that lower rainwater acidity. However, even though Yakushima's rain has an average acidity similar to that of Japan as a whole, the island receives three to four times the total deposition of atmospheric $\mathrm{H}^{+}$owing to the large amount of precipitation $(4,000$ to $8,000 \mathrm{~mm} /$ year). The substantial impact of acidic rainwater and of seawater on Yakushima's ecosystems can be seen in the low $\mathrm{pH}, \mathrm{Ca}$, and $\mathrm{HCO}_{3}$ levels and the high sea salt component in the island's streamwater. It can also be seen in the $\mathrm{Sr}$ isotope ratios of the soil water and of land plants, which are close to the marine values. $\mathrm{Sr}$ and $\mathrm{Nd}$ isotope data further suggest that the depletion of $\mathrm{Ca}$ in the exchangeable soil pool compared with values in the granitic parent materials is attributable to selective weathering of plagioclase and apatite and the recent accumulation of water- and acid-insoluble Asian dust silicates, and that these secondary minerals are not a vital part of the exchange of base cations with plants. Future monitoring of the geochemistry of streamwater, particularly regarding Ca losses, will be important to support preservation of the natural heritage site of Yakushima Island.

Acknowledgments This study was supported by a Global Environmental Fund grant (Acid Precipitation) from the Japan Environment Agency and by a Grant-in-Aid for Scientific Research Projects from the Ministry of Education, Culture, Sports, Science and Technology of Japan to T. N. (18201004). 
Open Access This article is distributed under the terms of the Creative Commons Attribution License which permits any use, distribution, and reproduction in any medium, provided the original author(s) and the source are credited.

\section{References}

Áberg, G. (1995). The use of natural strontium isotopes as tracers in environmental studies. Water, Air, and Soil Pollution, 79, 309-322.

Anma, R., Kawano, Y., \& Yuhara, M. (1998). Compositional zoning and its implication in a toroidal circulation inside the Yakushima pluton, SW Japan. Memoirs of National Institute of Polar Research, Special Issue. No. 53, 157-176.

Berner, E. K., \& Berner, R. A. (1987). The global water cycle. Englewood Cliffs: Prentice-Hall. 397.

Blum, J. D., Klaue, A., Nezat, C. A., Driscoll, C. T., Johnson, C. E., Siccama, T. G., Eagar, C., Fahey, T. J., \& Likens, G. E. (2002). Mycorrhizal weathering of apatite as an important calcium source in base-poor forest ecosystems. Nature, 417, 729-731.

Bory, A.J.M., Biscaye, P.E., \& Grousset, F.E. (2003). Two distinct seasonal Asian source regions for mineral dust deposited in Greenland (NorthGRIP) Geophysical Research Letters, 30(4). doi:10.1029/2002GL016446.

Chadwick, O. A., Derry, L. A., Vitousek, P. A., Huebert, B. J., \& Hedin, L. O. (1999). Changing sources of nutrients during four million years of ecosystem development. Nature, 397, 491-497.

Chun, Y., Boo, K.-O., Kim, J., Park, S.-U., \& Lee, M. (2001). Synopsis, transport, and physical characteristics of Asian dust in Korea. Journal of Geophysical Research, 106, 18461-18469.

Clow, D. W., Mast, M. A., Bullen, T. D., \& Turk, J. T. (1997). Strontium 87 /strontium 86 as a tracer of mineral weathering reactions and calcium sources in an alpine/subalpine watershed, Loch Vale, Colorado. Water Resources Research, 33(6), 1335-1351.

Ebise, S., \& Nagafuchi, O. (2002). Runoff characteristics of water quality and influence of acid rain on mountainous streamwaters on Yakushima Island. Japan Journal of Limnology, 63, 1-10 (in Japanese with English abstract).

Eguchi, T. (1984). Climate of Yaku-shima Island, especially regionality of precipitation distribution. In: Nature Conservation Bureau, Environment Agency, Japan (ed) Conservation Reports of the Yaku-shima Wilderness Area, Kyushu, Japan (in Japanese with English summary). Tokyo, 3-26.

Faure, G., \& Mensing, T.M. (2005). Isotopes, principles and applications. Third edition, John \& Wiley Sons, 897p.

Flanklyn, M. T., McNutt, R. H., Kamineni, D. C., Gascoyne, M., \& Fraps, S. K. (1991). Groundwater ${ }^{87} \mathrm{Sr} /{ }^{86} \mathrm{Sr}$ values in the Eye-Dashwa Lakes pluton, Canada: Evidence for plagioclase-water reaction. Chemical Geology, 86, 111-122.

Graustein, W. C. (1988). ${ }^{87} \mathrm{Sr} /{ }^{86} \mathrm{Sr}$ ratios measure the source and flow of strontium in terrestrial ecosystems. In P. W. Rundel, J. R. Ehleringer, \& R. A. Nagy (Eds.), Stable isotopes in ecological research 68. Ecological studies (pp. 491-512). New York: Springer.

Hartmann, J. (2009). Bicarbonate-fluxes and $\mathrm{CO}_{2}$-consumption by chemical weathering on the Japanese ArchipelagoApplication of a multi-lithological model framework. Chemical Geology, 265(3-4), 237-271.

Hartmann, J., Kunimatsu, T., \& Levy, J. K. (2008). The impact of Eurasian dust storms and anthropogenic emissions on atmospheric nutrient deposition in forested Japanese catchments and adjacent regional sea. Global and Planetary Change, 61, 117-134.

Hatakeyama, S., Takami, A., Sakamaki, F., Mukai, H., Sugimoto, N., \& Shimizu, A. (2004). Aerial measurement of air pollutants and aerosols during 20-22 March 2001 over the East China Sea. Journal of Geophysical Research, 109, D13304. doi:10.1029/2003JD004271.

Inoue, M., Ohara, T., Katayama, M., \& Murano, K. (2005). Annual Source-receptor relationships of sulfur in East Asia using a numerical simulation model RAMS/HYPACT. Journal of Aerosol Research, 20, 333-344 (in Japanese with English abstract).

Japan Environmental Sanitation Center. (2002). Acid Deposition and Oxidant Research Center (JESC-ADORC). CDROM of data sets of Japan acid deposition survey 20 by the Ministry of Environment.

Jones, E. V., Ragnarsdottir, K. V., Putnis, A., Bosbach, D., Kemp, A. J., \& Cressey, G. (1998). The dissolution of apatite in the presence of aqueous metal cations at $\mathrm{pH} 2-7$. Chemical Geology, 15, 215-233.

Kirkwood, D. E., \& Nesbitt, H. W. (1991). Formation and evolution of soils from an acidified watershed: Plastic Lake, Ontario, Canada. Geochimica et Cosmochimica Acta, 55, 1295-1308.

Kume, A., Nagafuchi, O., Akume, S., Nakatani, N., Chiwa, M., \& Tetsuka, K. (2010). Environmental factors influencing the load of long-range transported air pollutants on Pinus amamiana in Yakushima Island, Japan. Ecological Research, 25, 233-243.

Kurita, H., \& Ueda, H. (2006). Long-term decrease of $\mathrm{pH}$ of river and lake water in the uppermost stream part of the mountainous regions in central Japan: decrease of $\mathrm{pH}$ in the past 30 years in relation with acid rain. Journal Japan Society Atmosphere Environment, 41, 45-64 (in Japanese with English summary).

Kurosaki, Y., \& Mikami, M. (2003). Recent frequent dust events and their relation to surface wind in East Asia. Geophysical Research Letters, 30. doi:10.1029/2003gl017261.

Kurtz, A. C., Derry, L. A., \& Chadwick, O. A. (2001). Accretion of Asian dust in Hawaiian soils: isotopic, elemental, and mineral mass balances. Geochimica et Cosmochimica Acta, 65, 1971-1983.

Miller, E. K., Blum, J. D., \& Friedland, A. J. (1993). Determination of soil exchangeable-cation loss and weathering rates using $\mathrm{Sr}$ isotopes. Nature, 362, 438-441.

Mizota, C., Shimoyama, S., Kubota, M., Takemura, K., Iso, N., \& Kobayashi, S. (1992). Sources and ages of fine-grained soils developed on gentle slopes in Northern Kyushu. Quaternary Research, 31, 101-111 (in Japanese, with English Abstract).

Nagafuchi, O., Mukai, H., \& Koga, M. (2001). Black acidic rime ice in the remote island of Yakushima, a world natural heritage area. Water, Air, and Soil Pollution, 130, 1565-1570. 
Nagoya University (1991). Kousa, Kokon Shoin, Hydrospheric Atmospheric Research Center eds, 328p.

Nakahara, O., Takahashi, M., Sase, H., Yamada, T., Matsuda, K., Ohizumi, T., Fukuhara, H., Inoue, T., Takahashi, A., Kobayashi, H., Hatano, R., \& Hatakeyama, T. (2010). Soil and stream water acidification in a forested catchment in central Japan. Biogeochemistry, 97, 141-158.

Nakano, T., \& Tanaka, T. (1997). Strontium isotope constraints on the seasonal variation of the provenance of base cations in rain water at Kawakami, central Japan. Atmospheric Environment, 31, 4237-4245.

Nakano, T., Yoshino, T., \& Nishida, N. (1991). Rapid analytical method for trace $\mathrm{Zn}$ contents in some mafic minerals using the electron microprobe: Potential utility as a metallogenetic and petrogenetic indicator. Chemical Geology, 89, 379-389.

Nakano, T., Kasasaku, K., Minari, T., Satake, K., Yokoo, Y., Yamanaka, M., \& Ohde, S. (2000). Geochemical characteristics of wet precipitation on the deep-forest, mountains island of Yakushima, southern Japan, Sr isotopic signature of plant-derived $\mathrm{Ca}$ in rain. Global Environmental Research, 4, 39-48.

Nakano, T., Okumura, M., Yamanaka, M., \& Satake, K. (2001a). Geochemical characteristics of acidic stream water of Yakushima island, a world heritage site. Water, Air, and Soil Pollution, 130, 869-874.

Nakano, T., Yokoo, Y., \& Yamanaka, M. (2001b). Sr isotope constraint on the provenance of base cation in soilwater and streamwater in the Kawakami volcanic rock watershed, central Japan. Hydrological Process, 15, 1859-1875.

Nakano, T., Yokoo, Y., Anma, R., \& Shindo, J. (2001c). Ca depletion in the soil column on a granite substrate on the island of Yakushima, a world natural heritage site. Water, Air, and Soil Pollution, 130, 733-738.

Nakano, T., Yokoo, Y., Nishikawa, M., \& Koyanagi, H. (2004). Regional Sr-Nd isotopic ratios of soil minerals in north China as Asian dust fingerprints. Atmospheric Environment, 38, 3061-3067.

Nakano, T., Morohashi, S., Yasuda, H., Sakai, M., Aizawa, S., Shichi, K., Morisawa, T., Takahashi, M., Sanada, M., Matsuura, Y., Sakai, H., Akama, A., \& Okada, N. (2006). Determination of seasonal and regional variation in the provenance of dissolved cations in rain in Japan based on $\mathrm{Sr}$ and $\mathrm{Pb}$ isotopes. Atmospheric Environment, 40, 7409-7420.

Négrel, P., Petelet-Girand, E., Barbier, J., \& Gautier, E. (2005). Surface water-groundwater interactions in an alluvial plain: chemical and isotopic systematics. Journal of Hydrology, 277, 248-267.

Palmer, S. M., Wellington, B. I., Johnson, C. E., \& Driscoll, C. T. (2005). Landscape influences on aluminium and dissolved organic carbon in streams draining the Hubbard Brook valley, New Hampshire, USA. Hydrological Process, 19, 1751-1769. doi:10.1002/hyp. 5660.

Pett-Ridge, J.-C., Derry, L. A., \& Kurtz, A. C. (2009). Sr isotopes as a tracer of weathering processes and dust inputs in a tropical granitoid watershed, Luquillo Mountains, Puerto Rico. Geochimica et Cosmochimica Acta, 73, 25-43.
Richter, A., Burrows, J. P., Nüß, H., Granier, C., \& Niemeier, U. (2005). Increase in tropospheric nitrogen dioxide over China observed from space. Nature, 437, 129-132.

Rose, S., \& Fullagar, P. D. (2005). Strontium isotope systematic of base flow in Piedmont Province watersheds, Georgia (USA). Applied Geochemistry, 20, 1571-1586.

Satake, K., Inoue, T., Kasasaku, K., Nagafuchi, O., \& Nakano, T. (1998). Monitoring of nitrogen compounds on Yakushima Island, a world natural heritage site. Environmental Pollution, 102, 107-113.

Sato, T., \& Nagashima, H. (1979). Geology of the Seinanbu district in Yakushima. Quadrangle Series scale 1:50,000. Geological Survey of Japan, 47 p. (in Japanese with English abstract).

Schlesinger, W. H. (1997). Biogeochemistry: An analysis of global change (2nd ed., p. 588). New York: Academic Press.

Seto, S., Sato, M., Takanoe, T., Kusakari, T., \& Hara, H. (2007). Spatial distribution and source identification of wet deposition at remote EANET sites in Japan. Atmospheric Environment, 41, 9386-9396.

Shand, P., Darbyshire, D. P. F., Love, A. J., \& Edmunds, W. M. (2009). Sr isotopes in natural waters. Applications to source characterization and water-rock interaction in contrasting landscapes. Applied Geochemistry, 24, 574-586.

Shimizu, A., Sugimoto, N., Matsui, I., Arao, K., Uno, I., Murayama, T., Kagawa, N., Aoki, K., Uchiyama, A., \& Yamazaki, A. (2004). Continuous observations of Asian dust and other aerosols by polarization lidars in China and Japan during ACE-Asia. Journal of Geophysical Research, 109, D19S17. doi:10.1029/2002JD003253.

Tagawa, H. (1994). Natural World Heritage, Yakushima (in Japanese). Tokyo: Japan Broadcast Publishing. 187.

Takahashi, M., Sakata, T., \& Ishizuka, K. (2001). Chemical characteristics and acid buffering capacity of surface soils in Japanese forests. Water, Air, and Soil Pollution, 130, 727-732.

Tamaki, M., Katou, T., Sekiguchi, K., Kitamura, M., Taguchi, K., Oohara, M., et al. (1991). Acid precipitation chemistry over Japan. Chemical Society of Japan, 675-674 (in Japanese with English abstract).

Vitousek, P. M., \& Howarth, R. W. (1991). Nitrogen limitation on land and in the sea: How can it occur? Biogeochemistry, 13, 87-115.

White, A. F., Schulz, M. S., Lowenstern, J. B., Vivit, D. V., \& Bullen, T. D. (2005). The ubiquitous nature of accessory calcite in granitoid rocks: Implications for weathering, solute evolution, and petrogenesis. Geochimica et Cosmochimica Acta, 69(6), 1455-1471.

Xu, Z., Li, Y., Tang, Y., \& Han, G. (2009). Chemical and strontium isotope characterization of rainwater at an urban site in Loess Plateau, Northwest China. Atmospheric Research, 94, 481-490.

Yokoo, Y., Nakano, T., Nishikawa, M., \& Quan, H. (2004). Mineralogical variation of $\mathrm{Sr}-\mathrm{Nd}$ isotopic and elemental compositions in loess and desert sand from the central Loess Plateau in China as a provenance tracer of wet and dry deposition in the northwestern Pacific. Chemical Geology, 204(1-2), 45-62. 